\title{
Enflasyon ile Mevduat ve Kredi Faizleri Arasındaki İlişki: Türkiye İçin Fisher Eşitliği Çerçevesinde Ekonometrik Bir Analiz
}

Hüseyin USLU *

\section{Öz}

Bu çalışmanın amacı; TCMB tarafından enflasyon hedeflemesi rejiminin uygulandığı 2002:M012019:M01 döneminde, enflasyon ile faiz oranları arasındaki etkileşimi, ampirik olarak analiz etmektir. Çünkü Türkiye'de yüksek enflasyon sorunu devam etmektedir ve bunun nedenleri konusunda ekonomistler arasında ve ekonomistlerle siyasetçiler arasında bir takım görüş ayrılıkları bulunmaktadır. Bu yönüyle konu güncel ve ülke ekonomisi açısından önemlidir. Analizlerde kullanılan serilerin durağanlık dereceleri; $\mathrm{ADF}$, PP ve yapısal kırılmalı ADF birim kök testleriyle incelenmiş ve enflasyon serisinin birinci farkı alındığında, faiz serilerinin ise düzey değerlerinde durağan oldukları belirlenmiştir. Seriler farklı derecelerden durağan bulunduğu için seriler arasındaki eşbütünleşme ilişkilerinin Sınır Testi ile araștırılmış ve modellerde kullanılan seriler arasında eşbütünleșme ilişkisinin var olduğuna, yani bu serilerin uzun dönemde birlikte hareket ettiklerine karar verilmiştir. Uzun dönem analizleri, ARDL yöntemiyle yapılmış ve Türkiye'deki enflasyon oranı, ticari kredi faizlerindeki \%1 puanlık artışın \% 0.25 , mevduat faizlerindeki $\% 1$ puanlık artışı $\% 0.05$ puan artmış olduğu belirlenmiştir. Diğer yandan enflasyon oranındaki \%1 puanlık artışın, ticari kredi faizlerini $\% 0.23$ puan, vadeli mevduat faiz oranlarını $\% 0.59$ puan artırmış olduğu görülmüştür. Son olarak vadeli mevduat faiz oranlarındaki \%1 puanlık artışın ticari kredi faizlerini \%1.04 artırdığı bulunmuștur. Kısa dönem analizleri de ARDL yöntemiyle gerçekleştirilmiş ve modellerin hata düzeltme mekanizmalarının çalıştığı bulunmuştur. Ticari kredi faizlerinin kısa dönemde de enflasyonu artırdığı, ticari kredi faizlerinin, enflasyon ve vadeli mevduat faizleri tarafından artırıldığı belirlenmiştir. Ayrıca enflasyonun, kısa dönemde vadeli mevduat faizleri üzerindeki etkisinin istatistiksel olarak anlamlı olmadığı görülmüştür. Türkiye ekonomisinde Fisher Etkisi uzun dönemde geçerli iken, kısa dönemde geçerli çıkmamıștır. Seriler arasındaki nedensellik ilişkileri, Toda-Yamamoto yöntemiyle incelenmiş ve faiz oranlarından enflasyona doğru bir nedensellik ilişkisi söz konusu değilken, sadece enflasyondan vadeli mevduat faiz oranına doğru tek yönlü bir nedensellik ilişkisinin var olduğu bulunmuştur. $\mathrm{Bu}$ sonuç; teorik beklentilerimizle ve Fisher Eşitliği ile uyumludur. Yani Türkiye’deki yaygın söylemin aksine faizler enflasyonu değil, ekonomi teorisinde yer aldığı şekliyle enflasyon, faizi etkilemektedir. Enflasyon arttıkça, vadeli mevduat sahipleri, reel kazançlarını koruyabilmek için bankalardan daha fazla faiz talep etmektedirler.

Anahtar Kelimeler: Enflasyon, Mevduat Faiz Oranı, Kredi Faiz Oranı, Fisher Eşitliği. JEL Kodları: E31, G12, P44.

\footnotetext{
* Osmaniye Korkut Ata Üniversitesi, İktisadi ve İdari Bilimler Fakültesi, İşletme Bölümü,
} 


\title{
The Relationship Between Deposit Interest, Loan Interest And Inflation: An Econometric Analysis For Turkey in Terms of Fisher Equality
}

\begin{abstract}
The aim of this study is to empirically analyze the interaction between inflation and interest rates in the period 2002:M01-2019:M01, when the inflation targeting regime is implemented by the CBRT. Because high inflation problem continues in Turkey and no consensus among economists and among politicians and economists about the reasons can be reached, the issue is not old-fashioned and is still important for the national economy. The level of stationarity of the series in the analyzed are examined by using ADF, PP and structural break ADF unit root tests and it is determined that inflation series is stationary when the first difference and the interest series are stationary in level. Since the series are found to be stationary at different levels, the cointegration relationship between the series are investigated with the Bounds Testing and it is decided that there is a cointegration relationship between the series used in the models, that is, these series move together in the long term. Long-term analysis is conducted by ARDL method and it is found that $1 \%$ point increase in commercial loan interest and deposit interest rates incline the inflation rate by $0.25 \%$ and $0.05 \%$ in Turkey, respectively. On the other hand, the $1 \%$ increase in the inflation rate ascends the commercial loan interest rates by $0.23 \%$ and the time deposit interest rates by $0.59 \%$. Finally, it is determined that $1 \%$ increase in time deposits interest rates increase commercial loan interest rates by $1.04 \%$. Short-term analysis is also performed by ARDL method and error correction mechanisms of the models are found to operate. It is seen that commercial loan rates increase inflation in the short term, while commercial loan rates are positively influenced by inflation and time deposit rates. Moreover, it is observed that the effect of the inflation on the time deposit rates in the short term is not statistically significant. Fisher Effect is valid in the long term, but invalid in the short term. The causality relationships between the series are examined by Toda-Yamamoto method. There is no causal relationship from interest rates to inflation, but there is one-way causality relationship only from inflation to time deposit interest rate. This result is compatible with our theoretical expectations and Fisher Equality. So unlike the common rhetoric in Turkey, inflation is not affected from interest but inflation affect interest rates, as it is situated in the economy theory. As inflation increases, time deposit owners demand more interest from banks to maintain their real earnings.
\end{abstract}

Key Words: Inflation, Time Deposits Interest Rate, Credit Interest Rate, Fisher Equality. JEL Codes: E31, G12, P44.

\section{GIIRIs}

Enflasyon, halkın yakından hissettiği en önemli makroekonomik değişkenlerden biridir. Öyle ki ekonomi literatüründe enflasyon ile işsizliğin toplanmasıyla oluşturulmuş bir "Hoşnutsuzluk Endeksi" bile mevcuttur (Akpınar, Taşçı ve Özsan, 2013). Çünkü halk bu iki kavramın yüksek olmasından önemli ölçüde hoşnutsuz olmaktadır. Özellikle enflasyon ve işsizliğin birlikte yükseldiği dönemlerde ülkelerin reel gelir ve refah seviyeleri önemli ölçüde azalmakta, bu durum ülkelerde iktidar değişimlerine, sosyal patlamalara² ve

2-Aralık 2010'da Tunus'ta başlayan ve 15 ülkeyi etkisi altına alan Arap Baharı olaylarının temel nedeni; üniversite mezunu genç bir işsiz olan Muhammed Buazizi’nin seyyar satıclık yaptı̆̆ı tezgâhın zabıta görevlileri tarafından parçalanması ve hakkını aramaya çalıştığında kendisinin de darp edilmesi neticesinde kendisini yakması ve 
ülkelerin yönetim biçimlerinin değişimine ${ }^{3}$ kadar gidebilmektedir. ${ }^{4}$

Türkiye'de 1990'lı yıllarda, dönemsel olarak, \%100’ü aşan enflasyon altında yaşamış, ülkede gelir dengesi ve makroekonomik istikrar önemli ölçüde zarar görmüştür. Bu nedenle 1990’lı yıllarda ülkede sık sık hükümet değişiklikleri ve koalisyonlar yaşanmış, 1994 ve 2001 ekonomik krizleri meydana gelmiştir. 15 Nisan 2001'de açıklanan Güçlü Ekonomiye Geçiş Programı ile ülkede enflasyonu düşürebilmek için Türkiye Cumhuriyet Merkez Bankası (TCMB) tam özerk hale getirilmiş ve TCMB'ye temel sorumluluk alanı olarak "fiyat istikrarının sağlanması" görevi verilmiştir. Bunun üzerine TCMB 2002 yılından itibaren enflasyon hedeflemesi rejimine geçmiş, 2002-2005 döneminde örtük, 2006 ve sonrası dönemde açık enflasyon hedeflemesi sistemini uygulamaya başlamıştır (Eroğlu ve Eroğlu, 2009: 81-83). 2018 yılında iç ve dış nedenlerle Türkiye'de enflasyon tekrar hızla yükselmiş, TCMB’nin Ocak 2018'de \%7 olarak açıkladığı ve Hükümet Programında da yer verilen enflasyon hedefi, 2018 sonunda Tüketici Fiyatlarında (TÜFE) \%20.30, Üretici Fiyatlarında (ÜFE) \%33.64 olmuştur. ${ }^{5}$ Bu durum, Türkiye'de enflasyonun tekrar önemli bir makroekonomik sorun olma yolunda ilerlediğini göstermekte olup, enflasyonun nedenleri ve önlenebilmesine yönelik akademik çalışmalara ve politika önerilerine olan ihtiyacı artırmıştır.

Bu kapsamda çalışmada; Türkiyede enflasyonun nedenleri arasında gösterilen faizler mercek altına alınmış, mevduat ve kredi faizlerinin enflasyon üzerindeki etkileri, teorik ve uygulamalı olarak analiz edilmiştir. Girişi takiben çalışmanın birinci bölümünde; enflasyon ile faizler arasındaki ilişkinin teorik çerçevesi sunulmuş, ikinci bölümünde; Türkiye’deki enflasyon ve faiz oranları arasındaki ilişkiler, grafikler yardımıyla irdelenmiş, üçüncü bölümünde; literatürde yer alan çalışmaların kısa bir özeti sunulmuş, dördüncü bölümde ampirik analiz gerçekleştirilmiştir. Ampirik analiz için 2002:M01-2019:M01 dönemi faiz ve enflasyon verileri kullanılmış, Sınır Testi, ARDL ve Toda-Yamamoto nedensellik testi yöntemlerinden yararlanılmıştır. Sonuç ve önerilerle çalışma tamamlanmıştır. Ampirik analiz yapılırken; sadece enflasyonun faizler üzerindeki etkisine bakmakla yetinilmemiş, ayrıca faizlerin enflasyon üzerindeki etkileri de analiz edilmiştir. ${ }^{6} \mathrm{Bu}$ çalışmanın; incelenen

vefat etmesidir. Yani temel neden işsizliktir ve önemli bir sosyal patlamaya neden olmuştur. Konunun detayları için bakınız: [http://www.tarihiolaylar.com/tarihi-olaylar/arap-bahari-1304].

3-1929'da başlayıp 1933 yılına kadar devam eden Büyük Bunalımın etkisiyle ülkelerde işsizlik \%25'e kadar çıkmış, imalat sanayi üretimi \%50 oranında azalmış, fiyatlar genel düzeyi önemli ölçüde artmıştır. Bunun sonucunda; Almanyada Hitler, İtalya’da Musolluni, Japonya'da Meiji öncülüğünde dikdatöryal yönetimler işbaşına geçmiştir (Yıldırım, Karaman ve Taşdemir, 2009: 13; Sabancı, 2018: 297-299).

4-Günümüzde Venezüella'da yaşanan olaylar da bu konuda oldukça dikkate değerdir. Kasım 2018'de yıllık enflasyonun \%1.3 milyona ulaştığı Venezuella'da yaygın sokak olayları yaşanmakta ve Devlet Başkanı Mauro’ya karşı ulusal ve uluslararası tepkiler hızla yükselmektedir (Sözcü, 2018). Bu halkaya son olarak Sudan da katılmış bulunmaktadır. Ülke parasının son yıllarda \%2400 değer kaybettiği, döviz sıkıntısına bağlı olarak gıda ve ilaç sıkıntılarının yaşandığı Sudan'da yaygın halk gösterileri patlak vermiş ve bunun üzerine

5-Ekim 2018'de TÜFE \%25.24, ÜFE \%45.01 olmuş, alınan önlemlerle belirli ölçüde düşürülebilmiştir (ASMMMO, 2018).

6-Bilindiği üzere Türkiyede enflasyon ile faiz arasındaki etkileşimin yönü konusunda siyasetçiler ve ekonomistler farklı düşünmektedirler. Ekonomistler, mevcut kaynaklara/teorilere bakarak enflasyonun faizleri artırdığını 
konunun güncelliği ve ülke ekonomisi açısından önemi yanında, kullanılan veriler ve uygulanan analiz yöntemleri itibariyle de literatüre bir katkı sağlaması beklenmektedir.

\section{TEORIK ÇERÇEVE}

Enflasyon ile faiz oranı arasındaki teorik etkileşimi açıklamaya yönelik en bilinen yaklaşım, Fisher (1930) tarafından geliştirilen ve literatürde Fisher Eşitliği olarak yer edinen yaklaşımdır. Fisher (1930) bu yaklaşımda; cari dönem nominal faiz oranlarının $\left(i_{t}\right)$, beklenen reel faiz oranları $\left(r_{t}^{e}\right)$ ve beklenen enflasyonun $\left(\pi_{t}^{e}\right)$ bir fonksiyonu olduğu ifade etmekte ve bu ilişkiyi eşitlik (1)'deki gibi düzenlemektedir:

$i_{t}=r_{t}^{e}+\pi_{t}^{e}$

Rasyonel Bekleyişler Teorisine göre, ekonomik aktörler tam bilgiye sahiptirler ve beklenen enflasyon $\left(\pi_{t}^{e}\right)$, gerçekleşen enflasyona $\left(\pi_{t}\right)$ eşit kabul edilebilmektedir (Mishkin, 1991). Diğer yandan reel faiz oranlarının uzun dönemde sabit olduğu varsayılmaktadır (Fama, 1975; Cappock and Poitras, 2000 ). Bu durumda eşitlik (1) yeniden düzenlenerek:

$i_{t}=\bar{r}+\pi_{t}$

şekline getirilebilmektedir. Bu denklem ekonometrik formda yazıldığında:

$i_{t}=\beta_{0}+\beta_{1} \pi_{t}+\varepsilon_{t}$

eşitliğine ulaşılır. $\mathrm{Bu}$ denklem, cari dönem faiz oranlarının $\left(i_{t}\right)$, cari dönem enflasyonu $\left(\pi_{t}\right)$ ile yakın etkileşim içinde olduğunu göstermektedir. Fisher (1930), Denklem (3)'ü ABD’nin 1890-1927 dönemi verileriyle ve İngiltere'nin 1820-1924 dönemi verileriyle tahmin etmiş ve enflasyon oranı ile faiz oranı arasında $\beta_{-} 1 \cong 1$ bir ilişki tespit etmiştir. Bundan dolayı literatürde; Denklem (3)'te yer alan enflasyon ve faiz oranı serileri eşbütünleşik çıkar ve $\beta_{1}$ katsayısı da l'e yakın bulunursa, Fisher Eşitliğinin (veya Fisher Etkisinin) ilgili ekonomide geçerli olduğuna karar verilmektedir (Lee, 2007; Beyer, Haugh ve Dewald, 2009; Argyro, 2010).

\section{TÜRKIYY'DE ENFLASYON VE FAİZ ORANLARI}

Türkiye, 2000 yılı öncesi dönemde önemli ölçüde yüksek enflasyon sorunu ile baş etmek zorunda kalmıştır. Bu enflasyon nedeniyle ülkede reel gelirler düşmüş, ekonomik büyüme

ve öncelikle enflasyonu düşürmenin gerektiğini ifade ederken, siyasiler tersine faizlerin enflasyonu artırdığını, bunun için öncelikle faizlerin düşürülmesinin gerekli olduğunu dile getirmektedirler. Bu çalışmada tarafsız davranılarak, olay her iki açıdan da incelenmiştir. 
istikrarsız bir hal almıştır. Türkiye'de yaşanan enflasyon oranlarındaki değişimler Grafik 1 yardımıla incelenebilir.

\section{Grafik 1: Türkiye'de Enflasyon Oranları (1960-2018)}

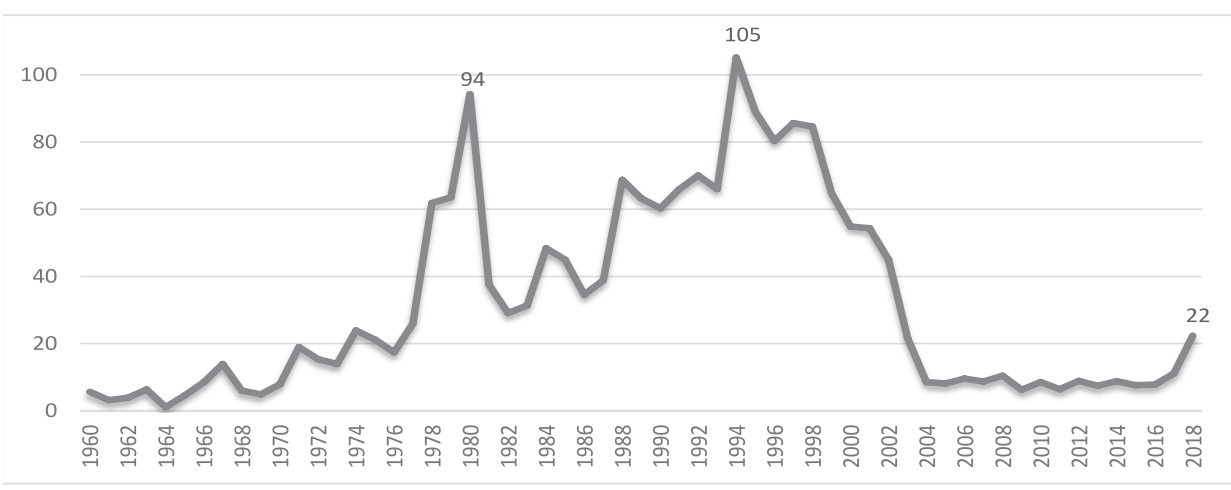

Kaynak: World Bank (2019a) ve EVDS (2019c).

Grafik 1'den görüldüğü gibi Türkiye ekonomisi 1970-2000 döneminde oldukça yüksek enflasyon oranları altında yaşamıştır. 1970-2000 dönemi ortalama enflasyon oranı \%51'dir. Bu oranın gelişmiş ülkelerde \%1'lerde olduğu düşünülürse, yaşanan enflasyonun şiddeti daha iyi anlaşılabilecektir. 2001 krizinden sonra uygulamaya konulan Güçlü Ekonomiye Geçiş Programı ve TCMB’nin özerk hale getirilip, tek hedef olarak fiyat istikrarını sağlaması görevinin verilmesinden sonra ülkede enflasyon hızla düşmüş, 20042016 döneminde ortalaması sadece \%8 olmuştur. Ancak Ağustos 2018'de döviz kurlarında yaşanan ani yükseliş ve buna bağlı olarak artan maliyetler nedeniyle 2018 yılı sonunda enflasyon \%20'nin üzerine çıkmıştır. 2000 öncesi dönemde yüksek enflasyon ile birlikte yüksek faiz oranları da Türkiye ekonomisinin en önemli makroekonomik sorunlarından biri olmuştur. Özellikle ekonomik kriz dönemlerinde daha hızlı artan faiz oranları, 1994'te \%88'e, 2001'de \%75'e ulaşmıştır.' Bir yıl vadeli mevduat faizi oranlarındaki dalgalanma Grafik 2 yardımıyla incelenebilir.

\footnotetext{
7-2001 krizi nedeniyle birkaç defa Hazine'nin borçlanma ihalelerine teklif gelmemiş, bu nedenle Mayıs 2001'de gecelik borçlanma faiz oranı \%7500'e yükselmiştir (Özatay, 2009).
} 


\section{Grafik 2: Türkiye'de Mevduat Faizi Oranları}

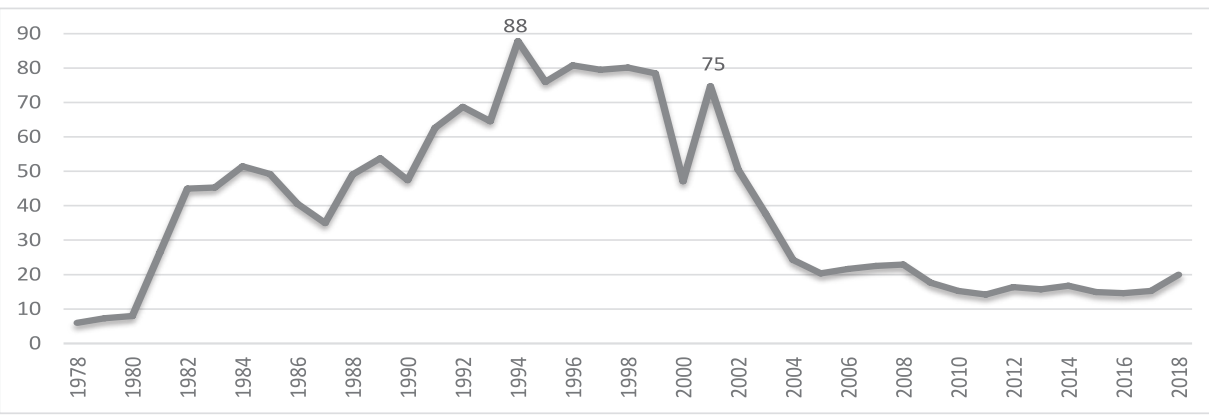

Kaynak: World Bank (2019b), EVDS (2019b).

Grafik 2'ye bakıldığında; 1980 sonrası dönemde faizlerin hızla arttığı, 1994’te \%88 ile zirveye ulaştığı, 2000 yılındaki kısmi düşüşün ardından, 2001 krizle birlikte \%75’e yükseldiği, enflasyonla mücadele programının uygulanmaya başlandığı 2002 sonrası dönemde ise hızla düştüğü görülmektedir. 1981-2000 dönemi ortalama faiz oranı \%58 gibi oldukça yüksek bir düzeydedir. Bu verinin gelişmiş ülkelerde \%1-2 aralığında değiştiği göz önüne alınırsa, ülkede yaşanan faizlerin yüksekliği daha net görülecektir. 2004-2016 dönemindeki ortalama faiz oranı \%18'dir ki bu da yüksektir. Enflasyon ile bir yıl vadeli mevduat faizleri arasındaki ilişkiler Grafik 3 yardımıyla incelenebilir.

\section{Grafik 3: Türkiye’de Enflasyon ile Mevduat Faizleri Arasındaki İlişkiler}

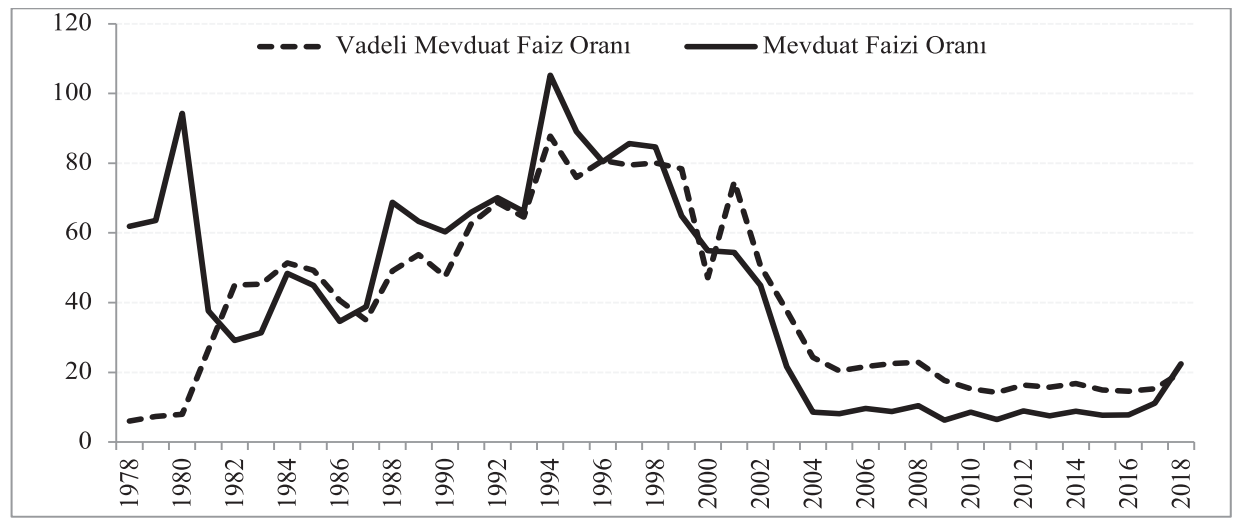

Kaynak: World Bank (2019a; 2019b), EVDS (2019b; 2019c).

Grafik 3’ten de görüldüğü üzere Türkiye ekonomisinde enflasyon ile faiz oranları arasında yakın bir etkileşim söz konusudur. Bu nedenle enflasyon ve faizle mücadele programlarının 
birlikte yürütülmesinin gerektiği ifade edilebilir.

\section{LİTERATÜR ÖZETI}

Konuyla ilgili son yıllarda yapılan ve ulaşılabilen ampirik çalışmaların kısa bir özeti, yayınlanma tarihi sırasına göre verilmiştir. Yamak ve Abdioğlu (2007), Türkiye ekonomisinde Fisher Hipotezinin geçerliliğini, 1990-2006 dönemine ait üçer aylık verileri kullanarak, Johansen ve Juselius eşbütünleşme Test ve VECM yöntemleri yardımıyla incelemiştir. Yazarlar bu çalışmada nominal faiz oranı ile tüketici fiyat endeksi verilerini almışlardır ve Türkiye ekonomisinde Fisher Etkisinin, hem güçlü, hem de zayıf formda geçerli olduğunu göstermişlerdir.Westerlund (2008), 20 OECD ülkesinde Fisher etkisinin geçerliliğini, 1980-2004 dönemi verilerini kullanarak, yatay kesit bağımlılığı altında yeni nesil panel veri analizi yöntemiyle incelemiş ve bu ülkelerde Fisher Etkisinin geçerli olduğunu, yani artan enflasyon oranının, nominal faiz oranının artırdığını tespit etmiştir. Etkinin en yüksek olduğu ülkelerin; Belçika, Kanada, İspanya, Japonya ve ABD olduğu belirlenmiştir. Sathye, Sharma ve Liu (2008), Hindistan'da Fisher Etkisinin geçerliliğini, 1996:M04-2004:M08 dönemi için Johansen-Juselius (1990) eşbütünleşme testi ve Granger nedensellik testi ile araştırmış ve Hindistan'da Fisher Etkisinin geçerli olduğunu, beklenen enflasyon oranından faiz oranına doğru kısa dönemli bir nedensellik ilişkisinin olduğunu tespit etmiştir.

Yılanc1 (2009), Türkiye’de Fisher Eşitliği Hipotezinin geçerliliğini, 1989:Q1 - 2008:Q1 dönemi için Engle ve Granger (1987) doğrusal ve Kapetanios vd. (2006) doğrusal olmayan eşbütünleşme testleri ile araştırmış ve Türkiye ekonomisinde ilgili dönemde Fisher Eşitliği Hipotezinin geçerli olmadığı sonucuna ulaşmıștır. Benazić (2013), Fisher Etkisinin Hırvatistan ekonomisinde geçerliliğini, 1996:M03-2012:M09 dönemi için Johansen eşbütünleşme testi ve VECM yöntemi yardımıyla analiz etmiş ve enflasyondaki \%1'lik artışın, faiz oranını \%0.709 oranında artırdığını tespit etmiştir. Jareño ve Tolentino (2013), Fisher Etkisinin Avrupa ülkelerinde geçerliliğini, 1997-2007 ve 2008-2012 dönemleri için EKK yöntemiyle karşılaştırmalı olarak analiz etmiş ve Fisher Etkisinin Avrupa ülkelerinde sadece kriz döneminde geçerli olduğunu belirlemiştir. Hatta Litvanya, Macaristan ve Hollanda'da Fisher Etkisinin kriz döneminde, ters yönde etkili olduğunu, yani artan faiz oranlarının enflasyonu yükselttiğini bulmuşlardır. Ayub vd. (2014), enflasyon ile faiz oranı arasındaki ilişkileri, Pakistan’ın 1973-2010 dönemi verilerini kullanarak, Johansen ve Engle ve Granger eşbütünleşme testleri ile analiz etmiş ve bu değişkenler arasında eşbütünleşme tespit ederek, bu değişkenlerin uzun dönemde birlikte hareket ettiklerini ifade etmişlerdir. Hacıoğlu ve Yerlikaya (2014), Türkiye ekonomisinde Fisher Hipotezinin geçerliliğini, beklentiler üzerinden, 1988:M01-2013:M05 dönemi, paranın satın alma gücü ve reel faiz verilerini kullanarak, ADF birim kök testi, Johansen (1990) eşbütünleşme testi ve Granger nedensellik testi ile analiz etmiştir. Eşbütünleşme testinde paranın satın alma gücü ve reel faiz değişkenleri arasında uzun dönemli bir eşbütünleşme ilişkisinin belirlendiği bu çalışmada, bu değişkenler arasında karşılıklı nedensellik ilişkilerinin 
var olduğu da bulunmuştur. Böylece ekonomik karar birimlerinin paranın değerine ilişkin beklentilerinin, reel faizler üzerinde etkili olduğu ve Fisher Hipotezinin Türkiye ekonomisinde geçerli olduğuna karar verilmiştir.

Andrea ve Rodrigo (2015), Fisher Etkisinin Meksika ekonomisinde geçerliliğini, 19962012 dönemi verilerini kullanarak, EKK yöntemiyle analiz etmiş ve ters yönlü bir Fisher Etkisi belirlemiştir. Buna göre; yıllık nominal faiz oranlarındaki \%1 puanlık artış, enflasyon oranını \%1.1982 puan artırmaktadır. Aylık nominal faiz oranlarındaki \%1 puanlık artışın ise enflasyon oranını \%2.2149 puan artırdığı belirlenmiştir. Yani vade kısaldığında, ters yönlü Fisher Etkisi güçlenmiştir. Babalola vd. (2015), Nijerya ekonomisinde enflasyon, faiz oranları ve ekonomik büyüme arasındaki ilişkileri, 1981-2014 dönemi verilerini kullanarak, EKK yöntemiyle analiz etmiş ve enflasyon ve faizlerdeki artışların, bu ülkede ekonomik büyümeyi olumsuz yönde etkilediğini tespit etmiştir. Doğan, Eroğlu ve Değer (2016), Türkiye ekonomisinde enflasyon ve faiz oranı arasındaki ilişkileri, 2003:M012015:M02 dönemi için ADF ve PP birim kök testleri, Johansen eşbütünleşme testi ve Granger nedensellik testi yardımıyla incelemiş ve enflasyondan faiz oranına doğru tek yönlü bir nedensellik ilişkisi bulmuştur. Tunalı ve Erönal (2016), enflasyon ile faiz oranı arasındaki ilişkiyi, Fisher Eşitliği çerçevesinde Türkiye’nin 2003:M01-2014:M02 dönemi verilerini kullanarak, yapısal kırılmalı Gregory ve Hansen (1996) eşbütünleşme testi ile incelemişler ve Türkiye’de Fisher Eşitliğinin uzun dönemde geçerli olduğunu, ancak kısa dönemde geçerli olmadığını tespit etmişlerdir.

Taban ve Şengür (2016), Türkiye'de enflasyonun nedenlerini belirlemeye yönelik olarak, 2003:M02-2014:M12 dönemi verilerini kullanarak yaptığı VAR analizi sonucunda; faiz oranlarından enflasyona doğru bir nedensellik ilişkisine rastlamazken, enflasyondan faize doğru tek yönlü bir nedensellik ilişkisi tespit etmiştir. Çalışmanın sonucunda; Türkiye’deki enflasyonun talep yönlü bir enflasyon olduğu tespitine yer verilmiştir. Torun ve Karanfil (2016), Türkiye ekonomisindeki enflasyon-faiz ilişkisini, 1980-2013 dönemi yıllık verilerini kullanarak, Johansen eşbütünleşme testi ve Granger nedensellik testi yardımıyla analiz etmiş, faiz oranları ve GSYH'den enflasyona doğru nedensellik ilişkileri tespit edilmiştir. Lebe ve Arda Özalp (2016), Türkiye ekonomisinde Fisher Eşitliğinin geçerliliğini, alternatif faiz oranları üzerinden, ARDL yöntemi yardımıyla sınamış ve politika faiz oranı ile enflasyon arasında güçlü bir ilişkinin olduğunu belirlemişlerdir. Adam ve Ofori (2017), Batı Afrika Ülkelerinde (Kape Verde, Gambiya, Gana, Nijerya ve Siere Leona) Fisher Etkisinin geçerliliğini, 1998:M02-2012:M08 dönemi için iki aşamalı Engle ve Granger eşbütünleşme testi ve EKK yöntemleriyle tahmin etmiş ve bu ülkelerde Fisher Etkisinin geçerli olmadığını belirlemiştir. Başar ve Karakuş (2017), Fisher Eşitliğinin Türkiye ekonomisinde geçerliliğini, 2004:M012-2016:M02 dönemi verilerini kullanarak, Engle ve Granger eşbütünleşme testi ve Granger nedensellik testi ile incelemiş ve mevduat faiz oranlarından enflasyon oranına doğru nedensellik ilişkisi tespit etmişlerdir. Alper (2017), enflasyon ile nominal faiz oranı arasındaki ilişkileri, Türkiye’nin 1973-2016 dönemi yıllık verilerini kullanarak, FMOLS yöntemiyle analiz etmiş ve enflasyon oranındaki \%1'lik artışın nominal faiz oranını \%0.77 oranında artırdığını belirlemiştir. 
Khumalo, Mutambara ve Assensoh-Kodua (2017), enflasyon ile faiz oranı arasındaki ilişkileri, Swaizeland için 2010-2014 dönemi özelinde incelemiş ve faiz oranlarının, enflasyonu artırdığını tespit etmiştir. Yıldız ve Başar (2018), enflasyon, faiz oranı ve döviz kuru arasındaki ilişkileri, Türkiye’nin 1984-2017 dönemi verilerini kullanarak Toda-Yamamoto nedensellik testi ile incelemişler ve faiz oranından enflasyona doğru tek yönlü bir nedensellik ilişkisi tespit etmişlerdir. Uribe (2018), ABD ekonomisinde YeniFisher Etkisinin geçerliliğini, optimize edilmiş model yardımıyla, 1954:Q3-2018:Q2 dönemi için analiz etmiş ve nominal faiz oranlarındaki artışların, enflasyon oranlarında hızlı bir düzeltmeye (yükselişe) neden olduğunu tespit etmiştir. Altunöz (2018), Çin ekonomisinde Fisher Eşitliğinin geçerliliğini 1996:Q01-2015:Q3 dönemi için Sınır Testi ve ARDL yöntemleriyle test etmiş ve bu ülkede Fisher Etkisinin geçerli olduğunu, yani artan enflasyonun, nominal faiz oranını artırdığını belirlemiştir.

Bayat, Kayhan ve Taşar (2018), kırılgan beşli ülkelerinde (Türkiye, Endonezya, Brezilya, Hindistan ve Güney Afrika) Fisher Eşitliğinin geçerliliğini, 2000:M01-2016:M06 dönemi verilerini kullanarak, yatay kesit bağımlılığını göz önünde bulundurarak yapılan yeni nesil panel nedensellik analizi yöntemleriyle incelemiş ve enflasyon ile nominal faiz oranları arasında Brezilya ve Endonezya'da karşılıklı, Güney Afrika ve Türkiye’de faiz oranlarından enflasyona doğru nedensellik ilişkileri belirlerken, Hindistan'da bu değişkenler arasında herhangi bir nedensellik ilişkisinin olmadığına karar vermiştir. Songur (2019), Türkiye’de Fisher Etkisi yaklaşımının geçerliliğini, 2002:Q1 - 2018:Q1 dönemi verilerini kullanarak, Becker, vd. (2006) Fourier KPSS birim kök testi ve Tsong vd. (2016) Fourier Shin eşbütünleşme testi ile analiz etmiş ve Fisher Etkisi yaklaşımının Türkiye’de geçerli olmadığını belirlemiştir.

Literatürde yer alan çalışmalarda genel olarak kredi faizleri ve mevduat faizleri şeklinde bir ayrıştırmaya gidilmediği görülmektedir. Bu çalışmanın, bu yönüyle de literatüre bir katkı sağlaması beklenmektedir.

\section{AMPİRIK ANALİZ}

\subsection{Veri Seti}

Enflasyon ile faiz oranları arasındaki etkileşimi analiz edebilmek için, TCMB tarafından enflasyon hedeflemesi rejiminin uygulandığı 2002:M01-2019:M01 döneminde bankalar tarafından ticari kredilere uygulanan ağırlıklandırılmış yıllık faiz oranı (KF), 1 yıl vadeli mevduatlara uygulanan ağırlıklandırılmış yıllık faiz oranı (MF) ve yıllık tüketici fiyatları endeksinden (TÜFE, 2003=100) hesaplanan yıllık enflasyon (ENF) verileri kullanılmıştır. Veriler TCMB Elektronik Veri Dağıtım Sisteminden (EVDS, 2019a, 2019b, 2019c)'den elde edilmiştir. Seriler, Moving Average (Hareketli Ortalamalar) yöntemiyle mevsim etkilerinden arındırılmıştır. Ayrıca analiz döneminde yer alan ve Türkiye ekonomisini de yakından etkileyen 2008 küresel ekonomik krizinin etkileri de kukla değişkenle $\left(K_{2008}\right)$ 
analizlere dâhil edilmiştir. Veri setine ait tanımlayıcı istatistikler Ek 1'de değişkenler arasındaki korelasyon matrisi Ek 2'de sunulmuştur. Ek 2'deki korelasyon matrisi sonuçlara göre; ticari kredi faizleri ve mevduat faizleri ile enflasyon arasında oldukça yüksek ilişkiler vardır. Diğer yandan mevduat faizleri ile ticari kredi faizleri arasındaki ilişkilerin çok daha yüksek (0.96) olduğu görülmektedir. Dolayısıyla bu değişkenler arasında yakın bir etkileşim vardır ve analizlerde birlikte kullanılmaları akla yatkındır. Bu çalışmada değişkenler arasında Grafik 4’teki gibi bir etkileşimin olduğu öngörülmektedir.

\section{Grafik 4: Değişkenler Arasındaki Muhtemel Etkileşimler}

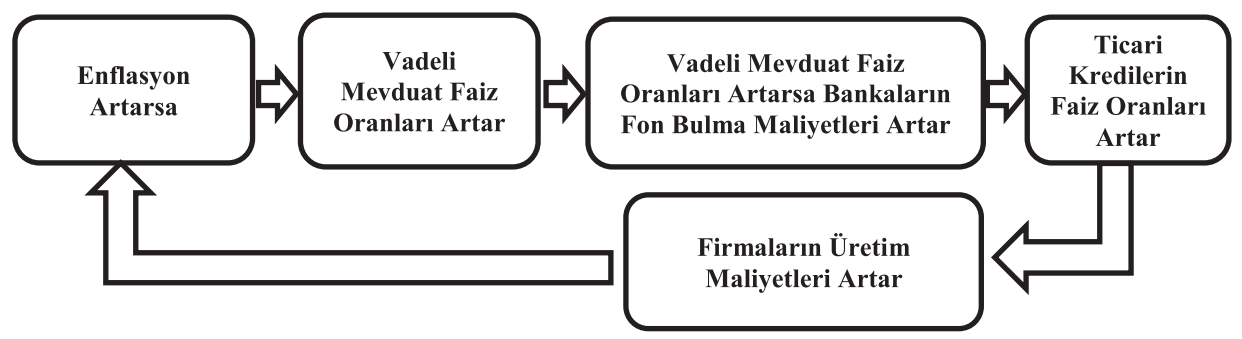

Kaynak: Mevcut literatür ve makroekonomik göstergeler çerçevesinde, yazar tarafindan oluşturulmuştur.

Yapılacak ampirik analizlerde bu öngörünün geçerliliği, farklı zaman serisi analizi yöntemleri yardımıyla test edilecektir.

\subsection{Model}

Çalışmada enflasyon ile faizler arasındaki ilişkileri ortaya çıkarabilmek için Fisher Eşitliği temel alınıp, Doğan, Eroğlu ve Değer (2016) izlenerek ve tarafımızdan mevduat faizleri ve kredi faizleri de eklenerek ve ayrıca bağımlı ve bağımsız değişkenlerin yerleri değiştirilerek, üç farklı ekonometrik model kurulmuştur:

Model 1: $E N F_{t}=\beta_{0}+\beta_{1} K F_{t}+\beta_{2} M F_{t}+\beta_{3} K_{2008}+u_{t}$

Model 2: $\quad K F_{t}=\alpha_{0}+\alpha_{1} E N F_{t}+\alpha_{2} M F_{t}+\alpha_{3} K_{2008}+v_{t}$

Model 3: $\quad M F_{t}=\gamma_{0}+\gamma_{1} E N F_{t}+\gamma_{2} K F_{t}+\gamma_{3} K_{2008}+e_{t}$

$\mathrm{Bu}$ modellerde yer alan ticari kredi faizleri; firmaların üretim maliyetlerinin (ve maliyet enflasyonunun) bir temsilcisi olurken, mevduat faizleri; bankaların fon bulma maliyetlerinin ${ }^{8}$ bir temsilcisi olarak analizlerde kullanılmıştır. Model (1)'de; Türkiye’de

8- Bankalar genel olarak piyasadan topladıkları vadeli mevduatları, üzerlerine belirli bir kâr marjı ve risk primi ekledikten sonra firmalara ve diğer kredi talep edenlere kullandırmaktadır. Bu nedenle, artan vadeli mevduat 
yaşanan enflasyon üzerinde kredi faizlerinin (üretim maliyeti) ve mevduat faizlerinin (kredi/fon maliyeti) etkilerini, Model (2)'de; kredi faizleri üzerinde enflasyon ve mevduat faizlerinin, Model (3)'te de; mevduat faizleri üzerinde de enflasyon ve kredi faizlerinin etkileri analiz edilecektir. Model (1)'de artan kredi faizleri ve mevduat faizlerinin enflasyonu artırması beklendiği için analizler sonucunda $\beta_{1}>0$ ve $\beta_{2}>0$ çı kması beklenmektedir. Model 2'de artan enflasyonun Fisher Eşitliği çerçevesinde faizleri artırması beklendiği için $\alpha_{1}>0$ çıkması beklenmektedir. Yine bu modelde artan mevduat faizi oranlarının, bankaların fon bulma maliyetlerini ve dolaylı olarak ticari kredi faizlerini artıracağı öngörüldüğü için, analizler sonucunda $\alpha_{2}>0$ çıkması beklenmektedir. Model 3'te enflasyondaki artışların, Fisher Eşitliği çerçevesinde faizleri artırması beklendiği için analizler sonucunda $\gamma_{1}>0$ çıkması beklenmektedir. Kredi faizlerinin, mevduat faizleri üzerindeki etkisi konusunda önsel bir beklenti söz konusu değildir.

\subsection{Yöntem}

Bu çalışmada serilerin durağanlıkları ADF (Augmented Dickey Fuller: Genişletilmiş Dickey Fuller), PP (Phillips-Perron) ve yapısal kırılmalı ADF birim kök testleriyle incelenmiştir. Seriler arasındaki eşbütünleşme ilişkileri Sınır Testi yöntemiyle araştırılmıştır. Modellerde kullanılan seriler arasındaki uzun ve kısa dönem ilişkileri, ARDL yöntemiyle analiz edilmiştir. Analizlerde kullanılan seriler arasındaki nedensellik ilişkileri Toda-Yamamoto yöntemiyle test edilmiştir.

\subsection{Birim Kök Testleri}

Ampirik analizlerin ilk aşamasında serilerin durağanlık derecelerinin belirlenmesi ve sonraki aşamalarda kullanılacak analiz yöntemlerinin buna göre seçilmesi yararlı olacaktır. Serilerin durağanlık dereceleri göz önünde bulundurulmadan yapılacak analizler, hatalı sonuçlar üretebilecektir. Çalışmada serilerin durağanlıkları ADF, PP ve Vogelsang \& Perron (1998) tarafından geliştirilen, yapısal kırılmalı ADF birim kök testiyle incelenmiştir. (Uslu, 2018b: 517). Bu testlerden ADF, Dickey ve Fuller (1981) tarafından geliştirilmiş olup, ampirik analizlerde en sık kullanılan birim kök testidir. PP, Phillips ve Perron (1988) tarafından geliştirilmiş olup, trend içeren serilerin durağanlı̆̆ını test etmede ADF'den daha güçlü kabul edilmektedir. Son test ise Vogelsang ve Perron (1998) tarafından geliştirilmiş, yapısal kırılmaları da göz önünde bulunduran ve kırılma tarihini içsel olarak belirleyebilen bir testtir. Bu testlerin hepsinin hipotezleri aynı olup;

\section{$\mathrm{H}_{0}$ : Seri Durağan Değildir.}

\section{$\mathrm{H}_{1}$ : Seri Durağandır.}

şeklindedir. Bu çalışmada üç birim kök testi de uygulanmış, elde edilen sonuçlar Tablo 2'de, Vogelsang ve Perron (1998) tarafından geliştirilen yapısal kırılmalı birim kök testi

kredi faizlerinin, bankaların fon toplama maliyetleri üzerinden, verdikleri kredi faizlerini etkilemesi beklenmektedir. 
tarafından belirlenen yapısal kırılma grafikleri Ek 3'de sunulmuştur.

Tablo 2: Birim Kök Testleri Sonuçları

\begin{tabular}{|c|c|c|c|c|c|c|c|}
\hline \multirow{2}{*}{ Seri } & \multicolumn{2}{|c|}{ ADF Testi } & \multicolumn{2}{c|}{ PP Testi } & \multicolumn{2}{c|}{ Yapısal Kırılmalı ADF Testi } \\
\cline { 2 - 8 } & $\begin{array}{c}\text { ADF Test } \\
\text { İstatistiği }\end{array}$ & $\begin{array}{c}\text { Olasılık } \\
\text { Değeri }\end{array}$ & $\begin{array}{c}\text { PP Test } \\
\text { İstatistiği }\end{array}$ & $\begin{array}{c}\text { Olasılık } \\
\text { Değeri }\end{array}$ & $\begin{array}{c}\text { ADF Test } \\
\text { İstatistiği }\end{array}$ & $\begin{array}{c}\text { Olasılık } \\
\text { Değeri }\end{array}$ & $\begin{array}{c}\text { Yapısal Kırılma } \\
\text { Tarihi }\end{array}$ \\
\hline ENF & -1.28 & 0.18 & $-6.13^{* * *}$ & 0.00 & -3.96 & 0.11 & $2004: \mathrm{M} 02$ \\
\hline KF & $-2.88^{* *}$ & 0.04 & $-4.28^{* * *}$ & 0.00 & $-5.08^{* * *}$ & 0.00 & $2003: \mathrm{M} 04$ \\
\hline MF & $-2.86^{*}$ & 0.05 & $-4.41^{* * *}$ & 0.00 & $-6.29^{* * *}$ & 0.00 & $2003: \mathrm{M} 04$ \\
\hline$\Delta \mathrm{ENF}$ & $-4.35^{* * *}$ & 0.00 & - & - & $-11.63^{* * *}$ & 0.00 & $2002: \mathrm{M} 06$ \\
\hline
\end{tabular}

Not: Optimum gecikme uzunluğu Akaike Kriterine göre belirlenmiştir. ${ }^{* *},{ }^{\star *}$ ve *; sırasıyla serinin istatistiksel olarak $\% 1, \% 5$ ve $\% 10$ düzeyinde durağan olduğunu ifade etmektedir. $\Delta$; ilgili serinin birinci farkının alındığını göstermektedir. Serilerin düzey değerleri için yapılan birim kök testlerinde sabitli ve trendli, birinci farkları için yapılan testlerde sabit terimli test yöntemleri kullanılmıştır. Bu seçim şeklinin nedeni; serilerin düzey değerlerinde trend gibi deterministik faktörlerin de bulunabileceği ve bu faktörlerin serinin durağanlığını etkileyebileceği, serilerin birinci farkı alındığında trend etkisinin genel olarak oryadan kalkıyor olmasıdır.

Tablo 2'deki sonuçlara göre; enflasyon serisi birinci farkta, faiz serileri ise düzey değerlerinde durağandır. Yani seriler farklı derecelerde durağandır. Test yöntemi tarafından belirlenen yapısal kırılma tarihlerine bakıldığında; 2002-2004 döneminde enflasyon ve faiz serilerinin önemli dalgalanmalar içerdiği, sonrasında durağan hale geldiği görülmektedir.

\subsection{Eşbütünleşme Testi}

Ampirik analizlerde kullanılan bütün seriler düzey değerlerinde durağan olmadığında, bu serilerin düzey değerleri kullanılarak gerçekleştirilecek uzun dönem analizlerinde sahte regresyon sorunu ile karşılaşılabilecektir (Granger ve Newbold, 1974). Böyle durumlarda seriler arasında eşbütünleşme ilişkisinin varlığının test edilmesi gerekmektedir. Seriler arasında bir eşbütünleşme ilişkisi tespit edilebildiğinde, bu serin düzey değerleriyle yapılacak uzun dönem analizleri sahte regresyon problemi barındırmayacaktır (Engle ve Granger, 1987) ve elde edilecek sonuçlar güvenilir olacaktır.

Analizlerde kullanılan serilerin hepsi aynı dereceden entegre olmuşlarsa (aynı miktarda farkları alındığında durağan hale geliyorlarsa), bu seriler arasında eşbütünleşme ilişkisinin varlı̆̆ı Engle ve Granger (1987) veya Johansen (1988) yöntemleriyle analiz edilebilmektedir (Tarı, 2012: 415-432). Ancak bu çalışmada olduğu gibi seriler farklı derecelerden entegre olduğunda (farklı derecelerde durağan bulunduğunda) Pesaran, Shin ve Smith (2001) tarafından geliştirilen Sınır Testi yaklaşımının kullanılması gerekmektedir. Bu testin yapılabilmesi için kurulan kısıtlanmamış hata düzeltme modelleri (Unrestricted Error Correction Model; UECM) aşağıda yer almaktadır. 


$$
\begin{aligned}
\Delta E N F_{t}=\beta_{0}+ & \sum_{i=1}^{m} \beta_{1 i} \Delta E N F_{t-1}+\sum_{i=0}^{n} \beta_{2 i} \Delta K F_{t-1}+\sum_{i=0}^{p} \beta_{3 i} \Delta M F_{t-i}+\beta_{4} E N F_{t-1}+\beta_{5} K F_{t-1} \\
& +\beta_{6} M F_{t-1}+u_{t} \\
\Delta K F_{t}=\alpha_{0}+ & \sum_{i=1}^{m} \alpha_{1 i} \Delta K F_{t-1}+\sum_{i=0}^{n} \alpha_{2 i} \Delta E N F_{t-1}+\sum_{i=0}^{p} \alpha_{3 i} \Delta M F_{t-i}+\alpha_{4} K F_{t-1}+\alpha_{5} E N F_{t-1} \\
& +\alpha_{6} M F_{t-1}+v_{t} \\
\Delta M F_{t}=\gamma_{0}+ & \sum_{i=1}^{m} \gamma_{1 i} \Delta M F_{t-1}+\sum_{i=0}^{n} \gamma_{2 i} \Delta E N F_{t-1}+\sum_{i=0}^{p} \gamma_{3 i} \Delta K F_{t-i}+\gamma_{4} M F_{t-1}+\gamma_{5} E N F F_{t-1} \\
& +\beta_{6} K F_{t-1}+e_{t}
\end{aligned}
$$

Burada $m$, $n$ ve $p$; optimum gecikme uzunlukları olup, $A I C, S B C$ veya $H Q C$ gibi bilgi kriterleri/ölçütler kullanılarak tespit edilebilmektedir. Yapılacak sınır testi sonuçlarının güvenilir olabilmesi için belirlenen optimum gecikme uzunluğuna sahip modelde ardışık içsel bağımlılık (otokorelasyon) ve değișen varyans sorunları olmamalıdır. Bu modellerden örneğin Denklem (7) için yapılacak Sınır Testinde; ; $\beta_{4}, \beta_{5} v e \beta_{6}^{\prime}$ ya kısıt uygulanarak bir $F$ istatistiği hesaplanmaktadır. Elde edilen $F$ istatistiği, üst sınır değerinden (kritik değerden) büyük olduğunda, seriler arasında eşbütünleşme ilişkisinin var olduğuna karar verilmektedir. Denklem (7) için yapılacak Sınır Testinin hipotezleri:

$\mathrm{H}_{0}: \beta_{4}=\beta_{5}=\beta_{6}=0$

$\mathrm{H}_{1}: \beta_{4} \neq \beta_{5} \neq \beta_{6} \neq 0$

$\mathrm{H}_{0}: \beta_{4}=0$

$\mathrm{H}_{1}: \beta_{4} \neq 0$

şeklindedir. (10) numaralı hipoteze ait hesaplanan $F$ istatistiği, Pesaran vd. (2001) çalışmasında yer alan kritik değerlerle karşılaştırılır. Denklem (7)'de yer alan serilerden biri I(1), diğeri I(0) olduğunda; $F$ istatistiği alt ve üst sınır değeri ile karşılaştırılır. Bu değer, üst kritik değerinden büyük olduğunda $H_{0}$ hipotezi reddedilir ve serilerin eşbütünleşik olduğuna karar verilir. Hesaplanan $F$ istatistiği alt kritik değerden küçük olduğunda seriler artasında eşbütünleşme ilişkisinin olmadığına karar verilirken, hesaplanan $F$ istatistiği, alt ve üst kritik değerler arasında kaldığında, seriler arasında eşbütünleşmenin varlığı konusunda kararsız kalınmaktadır. (Uslu, 2018c: 1526). Serilerin her ikisi de I(0) olduğunda, hesaplanan $F$ istatistiği sadece alt kritik değerle karşılaştırılır ve bu değerden büyük olduğunda, seriler arasında eşbütünleşme ilişkisinin var olduğuna karar verilir. Serilerin her ikisi de I(1) olduğunda, hesaplanan $F$ istatistiği sadece üst kritik değerle karşılaştırılır ve bu değerden büyük olduğunda, seriler arasında eşbütünleşme ilişkisinin var olduğuna karar verilir. Bununla birlikte seriler arasında eşbütünleşme ilişkisinin 
olabilmesi için $\beta_{4}$ katsayısına ait $t$ istatistiğinin de anlamlı olması gerekmektedir. Benzer hipotezler ve sınamalar Denklem (8) ve Denklem (9) için de geçerlidir. Bu çalışmada her bir model için ayrı ayrı Sınır Testi yapılmış ve elde edilen sonuçlar Tablo 3’te sunulmuştur.

Tablo 3: UECM Modeli Sonuçları

\begin{tabular}{|c|c|c|c|c|c|c|c|c|c|c|}
\hline \multirow{2}{*}{ Model } & \multirow{2}{*}{$k$} & \multirow{2}{*}{ F Ístatistiğ $i$} & \multicolumn{3}{|c|}{ Alt Sinır Değeri } & \multicolumn{3}{|c|}{ Üst Sınır Değeri } & \multirow{2}{*}{\multicolumn{2}{|c|}{$t$-ist. }} \\
\hline & & & $\% 10$ & $\% 5$ & $\% 1$ & $\% 10$ & $\% 5$ & $\% 1$ & & \\
\hline Model 1 & 2 & $28.23^{\star * *}$ & 2.63 & 3.1 & 4.13 & 3.35 & 3.87 & 5 & $\beta_{4}$ & $15.93^{* * *}$ \\
\hline Model 2 & 2 & $4.30^{*}$ & 3.17 & 3.79 & 5.15 & 4.14 & 4.85 & 6.36 & $a_{4}$ & $17.03^{* * *}$ \\
\hline Model 3 & 2 & $5.39^{* * *}$ & 2.63 & 3.1 & 4.13 & 3.35 & 3.87 & 5 & $\gamma_{4}$ & $18.43^{* * *}$ \\
\hline
\end{tabular}

Not: ${ }^{* *}$ ve ${ }^{*}$; istatistiksel olarak sırasıyla \%1 ve \%10 anlamlılık düzeyinde seriler arasında eşbütünleşme ilişkisini var olduğunu göstermektedir.

Tablo 3’teki sonuçlara göre; modeller için hesaplanan $F$ istatistikleri, üst sınır değerlerinden daha büyük olduğu için eşbütünleşmenin varlığı konusundaki ilk koşul sağlanmaktadır. İkinci hipotezin sağlanabilmesi için $\beta_{4}, \alpha_{4}$ ve $\delta_{4}$ ve katsayılarının $\mathrm{t}$ istatistiklerine bakıldığında, bu istatistiklerin de \%1 anlamlılık düzeyinde güvenilir olduğu görülmüştür. O halde modellerde kullanılan seriler arasında eşbütünleşme ilişkisi vardır. Yani seriler uzun dönemde birlikte hareket etmektedirler ve bu serilerin düzey değerleriyle yapılacak analizler sahte regresyon problemi barındırmayacaktır. Bu sonuç, literatürde yer alan Ayub vd. (2014) çalışmasıyla uyumludur. Bu sonuçtan hareketle, seriler arasındaki uzun dönem ilişkilerinin araştırılmasına geçilebileceğine karar verilmiştir.

\subsection{Uzun Dönem Analizi}

Modellerde kullanılan seriler arasındaki uzun dönem ilişkileri, ARDL yöntemiyle araştırılmıştır. ARDL yöntemi, Sınır Testi ile aynı sistematikle çalışmakta, bağımsız ve bağımlı değişkenlerin gecikmeli değerlerini de modelde açılayıcı değişken olarak kullanarak, dinamik bir analiz gerçekleştirmektedir. Bu çalışmada uzun dönem analizleri için kullanılan modeller:

$$
\begin{aligned}
& E N F_{t}=\beta_{0}+\sum_{i=1}^{m} \beta_{1 i} E N F_{t-1}+\sum_{i=0}^{n} \beta_{2 i} K F_{t-1}+\sum_{i=0}^{p} \beta_{3 i} M F_{t-i}+\sum_{i=0}^{q} \beta_{4 i} K_{2008}+u_{t} \\
& K F_{t}=\alpha_{0}+\sum_{i=1}^{m} \alpha_{1 i} K F_{t-1}+\sum_{i=0}^{n} \alpha_{2 i} E N F_{t-1}+\sum_{i=0}^{p} \alpha_{3 i} M F_{t-i}+\sum_{i=0}^{q} \alpha_{4 i} K_{2008}+v_{t} \\
& M F_{t}=\gamma_{0}+\sum_{i=1}^{m} \gamma_{1 i} M F_{t-1}+\sum_{i=0}^{n} \gamma_{2 i} E N F_{t-1}+\sum_{i=0}^{p} \gamma_{3 i} K F_{t-i}+\sum_{i=0}^{q} \gamma_{4 i} K_{2008}+e_{t}
\end{aligned}
$$


Bu modellerin tahmini sonucunda değişkenlerine ait uzun dönem katsayıları, aşağıdaki formüller yardımıyla hesaplanmıştır (Johnston ve Dinardo, 1997: 245):

$$
\begin{aligned}
& \beta_{2}=\frac{\sum_{i=0}^{n} \beta_{2 i}}{1-\sum_{i=1}^{m} \beta_{1 i}} \\
& \beta_{3}=\frac{\sum_{i=0}^{p} \beta_{3 i}}{1-\sum_{i=1}^{m} \beta_{1 i}} \\
& \beta_{4}=\frac{\sum_{i=0}^{q} \beta_{4 i}}{1-\sum_{i=1}^{m} \beta_{1 i}}
\end{aligned}
$$

Benzer eşitlikler Denklem (13) ve Denklem (14)'teki uzun dönem katsayılarının elde edilmesinde de geçerlidir. Bu modeller ARDL yöntemiyle ayrı ayrı tahmin edilmiş ve elde edilen sonuçlar Tablo 4'te sunulmuştur. Bu tahminlerin istikrarlı olduğuna dair CUSUM

\begin{tabular}{|c|c|c|c|c|c|c|}
\hline \multirow[b]{2}{*}{ Bağımsız Değişken } & \multicolumn{2}{|c|}{ Model 1} & \multicolumn{2}{|c|}{ Model 2} & \multicolumn{2}{|c|}{ Model 3} \\
\hline & Katsayı & $\begin{array}{c}\text { Olasılık } \\
\text { Değeri }\end{array}$ & Katsayı & $\begin{array}{c}\text { Olasılık } \\
\text { Değeri }\end{array}$ & Katsayı & $\begin{array}{c}\text { Olasılık } \\
\text { Değeri }\end{array}$ \\
\hline ENF & \multicolumn{2}{|c|}{ Bă̆ımlı Değisşken } & $0.23^{* *}$ & 0.01 & $0.59^{\star * \star}$ & 0.00 \\
\hline$K F$ & $0.25^{\star \star \star}$ & 0.00 & \multicolumn{2}{|c|}{ Bă̆ımlı Değişken } & 0.16 & 0.29 \\
\hline$M F$ & $0.05^{\star *}$ & 0.04 & $1.04^{\star * *}$ & 0.00 & \multicolumn{2}{|c|}{ Bağımlı Değişken } \\
\hline$K_{2008}$ & $-0.52^{\star \star *}$ & 0.00 & $-7.92^{\star * *}$ & 0.00 & 1.49 & 0.24 \\
\hline Sabit Terim & $4.67^{\star \star *}$ & 0.00 & $1.01^{\star * *}$ & 0.00 & $0.74^{\star \star \star}$ & 0.00 \\
\hline \multicolumn{7}{|c|}{ Model Güvenilirlik Testleri } \\
\hline $\mathbf{R}^{2}$ & 0.98 & - & 0.98 & - & 0.99 & - \\
\hline $\mathbf{R}^{-2}$ & 0.98 & - & 0.98 & - & 0.99 & - \\
\hline F İstatistiği & 883.33 & 0.00 & 1298.60 & 0.00 & 2170.11 & 0.00 \\
\hline DW Ístatistiği & 1.99 & & 1.97 & & 2.04 & \\
\hline BG İstatistiği & 0.05 & 0.80 & 0.03 & 0.85 & 1.90 & 0.16 \\
\hline Harvey İstatistiğ i & 9.19 & 0.75 & 26.49 & 0.22 & 48.52 & 0.00 \\
\hline RR İstatistiği & 1.89 & 0.17 & 0.23 & 0.63 & - & - \\
\hline JB İstatistiği & 16.29 & 0.00 & 63.22 & 0.00 & 170.05 & 0.00 \\
\hline
\end{tabular}
ve CUSUMQ grafikleri Ek 4'te sunulmuştur.

Tablo 4: Uzun Dönem Analizi

Not: ${ }^{* *}$ ve ${ }^{* *}$; elde edilen katsayıların istatistiksel olarak sırasıly $\% 5$ ve \%1 önem düzeyinde güvenilir olduğunu göstermektedir.

Tablo 4'teki sonuçlara göre; Model 1'de 2002-2019 döneminde Türkiye'deki enflasyon oranı, kredi faizlerindeki \%1 puanlık artıştan \%0.25, mevduat faizlerindeki \%1 puanlık artıştan \%0.05 puan artmıştır. Bu sonuç, literatürde yer alan Alper (2017) çalışmasıyla uyumludur. Bu sonuçlara dayanarak; Türkiye'de enflasyonun, maliyet (KF) kaynaklı olduğu 
söylenebilir. Mevduat faizlerinin enflasyon üzerindeki etkisinin düşük olmasının nedeni, Türkiye'de faaliyet gösteren bankaların sadece halktan topladıkları mevduatları değil, yurtdışından aldıkları sendikasyon kredilerini de iç piyasaya kredi olarak kullandırıyor olmalarıdır. 2008 küresel ekonomik krizinin de enflasyonu azaltıcı etkilerinin olduğu görülmekte olup, bu durumun nedeninin, ülke içinde düşen talebi yükseltebilmek ve krizin etkilerini azaltabilmek için hükumet tarafından Nisan 2009-Eylül 2009 döneminde uygulanan KDV ve ÖTV indirimleri olduğu değerlendirilmektedir.

Model 2'de; kredi faizlerinin, enflasyondaki ve mevduat faizlerindeki artışlardan önemli ölçüde etkilendiği görülmektedir. Kredi faizlerini; enflasyondaki \%1 puanlık artışın $\% 0.23$, mevduat faizlerindeki \%1 puanlık artışın \%1.04 puan artırdığı görülmektedir. Burada mevduat faizlerindeki artışın, kredi faizleri üzerindeki etkisinin yüksek olması, Türkiye'deki kredi faizlerinin artışının önemli bir nedeninin, bu krediler için katlanılan fon maliyetlerindeki artış olduğu görülmektedir. Ancak enflasyonun da kredi faizlerinin önemli bir belirleyicisi durumunda olduğu unutulmamalıdır. 2008 küresel ekonomik krizinin Türkiye'deki ticari kredi faizlerini düşürücü yönde etki etmiştir. Bu durumun nedeni; o dönemde hükumet tarafından bankalara yapılan çağrılar ve TCMB tarafından uygulanan genişletici para politikaları sayesinde bankaların kredi verilebilir fon miktarlarının artması olduğu değerlendirilmektedir.

Model 3'te; enflasyondaki atışların, Fisher Eşitliğiyle uyumlu biçimde mevduat faizlerini artırdığ görülmektedir. Enflasyondaki \%1 puanlık artışın mevduat faizlerini \%0.59 puan artırdığ ${ }_{1}$ belirlenmiştir. Bu durumda, Türkiye ekonomisinde, 2002-2019 döneminde Fisher Etkisi geçerlidir. Kredi faizlerinin ve 2008 küresel ekonomik krizinin, mevduat faizleri üzerinde istatistiksel olarak anlamlı bir sonuca ulaşılamamıştır. Tablonun alt bölümünde yer alan Model Güvenilirlik Testleri sayesinde, yapılan analizlerin güvenilir olduğu görülmektedir.

\subsection{K1sa Dönem Analizi}

Çalışmada kısa dönem analizleri de ARDL yöntemiyle yapılmıştır. Kısa dönem analizlerinde, serilerin birinci farkı alınmış halleri ve uzun dönem analizinde elde edilen hata düzeltme terimi (Error Correction Term: $E C T_{t-1}$ ) kullanılmıştır. Kısa dönem analizi için çalışmada kullanılan modeller: 


$$
\begin{aligned}
& \Delta E N F_{t}=\beta_{0}+\sum_{i=1}^{m} \beta_{1 i} \Delta E N F_{t-1}+\sum_{i=0}^{n} \beta_{2 i} \Delta K F_{t-1}+\sum_{i=0}^{p} \beta_{3 i} \Delta M F_{t-i}+\sum_{i=0}^{q} \beta_{4 i} \Delta K_{2008} \\
& +\beta_{5} E C T 1_{t-1}+u_{t} \\
& \Delta K F_{t}=\alpha_{0}+\sum_{i=1}^{m} \alpha_{1 i} \Delta K F_{t-1}+\sum_{i=0}^{n} \alpha_{2 i} \Delta E N F_{t-1}+\sum_{i=0}^{p} \alpha_{3 i} \Delta M F_{t-i}+\sum_{i=0}^{q} \alpha_{4 i} \Delta K_{2008} \\
& +\alpha_{5} E C T 2_{t-1}+v_{t} \\
& \Delta M F_{t}=\gamma_{0}+\sum_{i=1}^{m} \gamma_{1 i} \Delta M F_{t-1}+\sum_{i=0}^{n} \gamma_{2 i} \Delta E N F_{t-1}+\sum_{i=0}^{p} \gamma_{3 i} \Delta K F_{t-i}+\sum_{i=0}^{q} \gamma_{4 i} \Delta K_{2008} \\
& +\gamma_{5} \text { ECT }_{t-1}+e_{t}
\end{aligned}
$$

$\mathrm{Bu}$ modellerin tahmini sonucunda hata düzeltme terimlerinin katsayıları negatif ve istatistiksel olarak anlamlı çıktığında, modellerin hata düzeltme mekanizmalarının çalıştığına karar verilmektedir. Yani uzun dönemde eşbütünleşme ilişkisi içinde hareket eden seriler arasında kısa dönemde meydana gelen sapmalar da ortadan kalktığına ve serilerin tekrar uzun dönemli eşbütünleşme ilişkisine yakınsadıkları anlaşılmaktadır (Tarı, 2012: 433-435). Bu durum, yapılan uzun dönem analizlerinin güvenilir olduğuna ek bir kanıt daha sağlar. Çalışmada bu modeller ARDL yöntemiyle ayrı ayrı tahmin edilmiş ve elde edilen sonuçlar Tablo 5 'te sunulmuştur. 
Tablo 5: Kisa Dönem Analizi

\begin{tabular}{|c|c|c|c|c|c|c|}
\hline \multirow[b]{2}{*}{ Bağımsız Değişken } & \multicolumn{2}{|c|}{ Model 1} & \multicolumn{2}{|c|}{ Model 2} & \multicolumn{2}{|c|}{ Model 3} \\
\hline & Katsayı & Olasılık Değeri & Katsayı & $\begin{array}{c}\text { Olasılık } \\
\text { Değeri }\end{array}$ & Katsayı & $\begin{array}{c}\text { Olasılık } \\
\text { Değeri }\end{array}$ \\
\hline$\Delta \mathrm{ENF}$ & \multicolumn{2}{|c|}{ Bağımlı Değişken } & $0.39^{* * *}$ & 0.00 & 0.02 & 0.62 \\
\hline$\Delta \mathrm{ENF}_{t-1}$ & $0.16^{*}$ & 0.01 & - & - & 0.03 & 0.38 \\
\hline$\Delta \mathrm{ENF}_{t-2}$ & -0.09 & 0.10 & - & - & 0.01 & 0.73 \\
\hline$\Delta \mathrm{ENF}_{t-3}$ & - & - & - & - & $-0.09^{* * *}$ & 0.00 \\
\hline$\Delta \mathrm{KF}$ & $0.33^{\star * \star}$ & 0.00 & \multicolumn{2}{|c|}{ Bağımlı Değişken } & $0.16^{\star * *}$ & 0.00 \\
\hline$\Delta \mathrm{KF}_{t-1}$ & $0.14^{* *}$ & 0.01 & $0.19^{\star * *}$ & 0.00 & -0.02 & 0.49 \\
\hline$\Delta \mathrm{KF}_{t-2}$ & $0.10^{*}$ & 0.06 & $-0.15^{\star \star \star}$ & 0.00 & $0.09^{\star *}$ & 0.01 \\
\hline$\Delta \mathrm{KF}_{t-3}$ & - & - & $0.17^{\star * *}$ & 0.00 & $0.08^{\star *}$ & 0.01 \\
\hline$\Delta \mathrm{MF}$ & - & - & $0.45^{\star * \star}$ & 0.00 & \multicolumn{2}{|c|}{ Bağımlı Değişken } \\
\hline$\Delta \mathrm{MF}_{t-1}$ & - & - & $-0.22^{* *}$ & 0.04 & $0.39^{* * *}$ & 0.00 \\
\hline$\Delta \mathrm{MF}_{t-2}$ & - & - & - & - & -0.11 & 0.10 \\
\hline$\Delta \mathrm{K}_{2008 t}$ & -0.14 & 0.82 & -0.03 & 0.95 & - & - \\
\hline$\Delta \mathrm{K}_{2008 t-1}$ & $-1.63^{\star *}$ & 0.01 & $1.31^{\star}$ & 0.05 & - & - \\
\hline$\Delta \mathrm{K}_{2008 t-2}$ & $-1.28^{\star}$ & 0.05 & $1.67^{* *}$ & 0.01 & - & - \\
\hline$\Delta \mathrm{K}_{2008 t-3}$ & $-1.28^{\star}$ & 0.05 & 1.07 & 0.13 & - & - \\
\hline$E C T_{t-1}$ & $-0.08^{* * *}$ & 0.00 & $-0.10^{\star * *}$ & 0.00 & $-0.09^{* * *}$ & 0.00 \\
\hline \multicolumn{7}{|c|}{ Model Güvenilirlik Testleri } \\
\hline $\mathbf{R}^{2}$ & 0.50 & - & 0.45 & - & 0.47 & - \\
\hline $\mathbf{R}^{-2}$ & 0.48 & - & 0.42 & - & 0.44 & - \\
\hline F İstatistiği & 883.33 & 0.00 & 1298.60 & 0.00 & 2170.11 & 0.00 \\
\hline DW İstatistiği & 1.99 & & 1.97 & & 2.04 & \\
\hline BG İstatistiği & 0.05 & 0.80 & 0.03 & 0.85 & 1.90 & 0.16 \\
\hline Harvey İstatistiği & 9.19 & 0.75 & 26.49 & 0.22 & 48.52 & 0.00 \\
\hline$R R$ İstatistiği & 1.89 & 0.17 & 0.23 & 0.63 & - & - \\
\hline JB İstatistiği & 16.29 & 0.00 & 63.22 & 0.00 & 170.05 & 0.00 \\
\hline
\end{tabular}

Not: ${ }^{* *}$ ve ${ }^{* * *}$; elde edilen katsayıların istatistiksel olarak sırasıyla $\% 5$ ve $\% 1$ önem düzeyinde güvenilir olduğunu göstermektedir.

Tablo 5’teki sonuçlara bakıldığında; modellerin hata düzeltme terimlerinin katsayılarının negatif ve istatistiksel olarak anlamlı oldukları görülmektedir. O halde modellerin hata düzeltme mekanizmaları çalışmaktadır ve yapılan uzun dönem analizleri güvenilirdir. Model 1 için yapılan kısa dönem analizinde; kredi faizlerinin kısa dönemde de enflasyonu artırdığ 1 görülmektedir. Model 2 için yapılan analizde; ticari kredi faizlerinin, enflasyon ve vadeli mevduat faizleri tarafından artırıldığı belirlenmiştir. Model 3 için yapılan analizde; enflasyonun, kısa dönemde vadeli mevduat faizleri üzerindeki etkisinin istatistiksel olarak anlamlı olmadığı görülmüştür. Yani Türkiye ekonomisinde kısa dönemde Fisher Etkisi yoktur. Bu durum, fon sahiplerinin, enflasyondaki değişimler karşısında kendilerini hemen korumaya alamadıklarını göstermektedir. 


\subsection{Nedensellik Testi}

Nedensellik testleri; seriler arasındaki etkileşimin varlığı ve yönü hakkında bilgiler

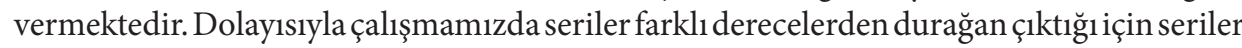
arasındaki nedensellik ilişkilerinin Toda-Yamamoto (1995) yöntemiyle analiz edilmesi gerekmektedir. (Uslu, 2018a: 79). Bu yöntemde $Y$ ve $X$ şeklindeki iki değişken arasındaki nedensellik ilişkileri aşağıdaki denklem sistemi yardımıyla araştırılabilmektedir:

$$
\begin{gathered}
Y_{t}=\psi_{0}+\sum_{i=1}^{m+d_{\max }} \psi_{1 i} Y_{t-i}+\sum_{i=1}^{m+d_{\max }} \psi_{2 i} X_{t-i}+e_{t} \\
X_{t}=\xi_{0}+\sum_{i=1}^{m+d_{\max }} \xi_{1 i} X_{t-i}+\sum_{i=1}^{m+d_{\max }} \xi_{2 i} Y_{t-i}+\varepsilon_{t}
\end{gathered}
$$

Burada $m$; ideal gecikme uzunluğunu, $d_{\text {max }}$; serilerin en büyük entegre olma derecesini göstermektedir. $\mathrm{Bu}$ modeller tahmin edildikten sonra $d_{\max }$ 'ten elde edilen katsayılara sınırlamalar konulmakta ve bu șekilde bir WALD test istatistiği elde edilmektedir. (Uslu, 2018a: 79). Denklem (21); X’ten Y'ye, Denklem (22); Y'den X'e doğru bir nedensellik ilişkisinin varlığını araştırmaya imkân vermektedir. Denklem (16) için test edilecek hipotezler;

\section{$\mathrm{H}_{0}: \Psi_{2 \mathrm{i}}=0 \quad X ’$ ten $Y^{\prime}$ ye Doğru Bir Nedensellik Yoktur \\ $\mathrm{H}_{1}: \Psi_{2 \mathrm{i}} \neq 0 \quad X^{\prime}$ ten $Y^{\prime}$ ye Doğru Bir Nedensellik Vardır}

şeklindedir. Toda-Yamamoto (1995) nedensellik testi yapılırken, öncelikle ideal gecikme uzunluğunun $(m)$ belirlenmesi gerekmektedir. Bunun için standart bir VAR tahmini yapılıp, VAR içinde yer alan bilgi kriterlerinden yararlanılır. Bu çalışmada ideal gecikme uzunluğu belirleme işlemi yapılmış ve sonuçları Ek 5’te sunulmuştur. Burada elde edilen sonuçlara göre; LR, FPE ve AIC kriterlerine dayanarak, ideal gecikme uzunluğu 7 alınmıştır'. Buna, seriler en fazla 1 defa farkı alındığında durağan hale geldiği için $d_{\max }=1$ değeri de eklenerek, 8 gecikme ile Toda-Yamamoto (1995) nedensellik testi yapılmış ve elde edilen sonuçlar Tablo 6'da sunulmuştur.

\footnotetext{
9-(7) gecikmeli VAR modelinin istikrarlı olduğuna ilişkin ters polinomal karakteristik kökler grafiği Ek 6’da sunulmuştur.
} 
Tablo 6: Toda-Yamamoto Nedensellik Testi Sonuçları

\begin{tabular}{|l|c|c|l|}
\hline Nedenselliğin Yönü & $\begin{array}{c}\text { Chi-Sq. Test } \\
\text { Stat. }\end{array}$ & Prob. & \multicolumn{1}{|c|}{ Karar } \\
\hline $\mathrm{KF} \Rightarrow \mathrm{ENF}$ & 11.47 & 0.17 & KF'den $E N F^{\prime}$ na Doğru Bir Nedensellik Yoktur \\
\hline $\mathrm{MF} \Rightarrow \mathrm{ENF}$ & 5.25 & 0.73 & $M F^{\prime}$ den $E N F^{\prime} y e$ Doğru Bir Nedensellik Yoktur \\
\hline $\mathrm{ENF} \Rightarrow \mathrm{KF}$ & 3.44 & 0.90 & ENF'ten $K F^{\prime}$ ye Doğru Bir Nedensellik Yoktur \\
\hline $\mathrm{ENF} \Rightarrow \mathrm{MF}$ & $\mathbf{1 4 . 1 3}^{*}$ & $\mathbf{0 . 0 7}$ & ENF'ten $M F^{\prime}$ ye Doğru Bir Nedensellik Vardır \\
\hline $\mathrm{MF} \Rightarrow \mathrm{KF}$ & 9.27 & 0.31 & $M F^{\prime}$ ten $K F^{\prime}$ ye Doğru Bir Nedensellik Yoktur \\
\hline $\mathrm{KF} \Rightarrow \mathrm{MF}$ & 12.73 & 0.12 & KF'ten $M F^{\prime}$ ye Doğru Bir Nedensellik Yoktur \\
\hline
\end{tabular}

Not: *; istatistiksel olarak \%10 güven düzeyinde birinci değişkenden ikinci değişkene doğru bir nedensellik ilişkisinin var olduğunu göstermektedir.

Tablo 6'daki sonuçlara göre; faiz oranlarından enflasyona doğru bir nedensellik ilişkisi söz konusu değilken, enflasyondan vadeli mevduat faiz oranına doğru tek yönlü bir nedensellik ilişkisi vardır. Bu sonuç; teorik beklentilerimizle ve Fisher Eşitliği ile de uyumludur. Aynı zamanda literatürde yer alan Doğan, Eroğlu ve Değer (2016); Taban ve Şengür (2016); Torun ve Karanfil (2016); Başar ve Karakuş (2017); Yıldız ve Başar (2018) çalışmalarıyla da tutarlılık göstermektedir. Yani Türkiye’deki yaygın söylemin aksine faizler enflasyonu değil, ekonomi teorisinde yer aldığı şekliyle enflasyon, faizi etkilemektedir. Enflasyon arttıkça, vadeli mevduat sahipleri, reel kazançlarını koruyabilmek için bankalardan daha fazla faiz talep etmektedirler.

\section{SONUÇ VE ÖNERİLER}

Bu çalışmada enflasyon ile faiz oranları arasındaki etkileşimi analiz edebilmek için, TCMB tarafından enflasyon hedeflemesi rejiminin uygulandığ 2002:M01-2019:M01 döneminde bankalar tarafından ticari kredilere uygulanan ağırlıklandırılmış yıllık faiz oranı (KF), bir yıl vadeli mevduatlara uygulanan ağırlıklandırılmış yıllık faiz oranı (MF) ve tüketici fiyatları endeksinden hesaplanan yıllık enflasyon oranı (ENF) verileri kullanılmıştır. Yapılan korelasyon analizinde; enflasyon ile faiz oranları arasında oldukça yüksek bir ilişkinin olduğu görülmüştür. Ampirik analiz çerçevesinde üç farklı ekonometrik model kurulmuş, 2008 küresel ekonomik krizi de bu modellere kukla değişkenle dâhil edilmiştir.

Analizlerde kullanılan serilerin durağanlık dereceleri; ADF, PP ve yapısal kırılmalı ADF birim kök testleriyle incelenmiş ve enflasyon serisinin birinci farkı alındığında, faiz serilerinin ise düzey değerlerinde durağan oldukları belirlenmiştir. Seriler farklı derecelerden durağan bulunduğu için seriler arasındaki eşbütünleşme ilişkilerinin Sınır Testi ile araştırılması gerektiğine karar verilmiştir. Yapılan Sınır Testleri sonucunda; modellerde kullanılan seriler arasında eşbütünleşme ilişkisinin var olduğuna, yani bu serilerin uzun dönemde birlikte hareket ettiklerine karar verilmiştir. 
Uzun dönem analizleri, serilerin düzey değerleri kullanılarak, ARDL yöntemiyle yapılmış ve 2002-2019 döneminde Türkiye'deki enflasyon oranı, ticari kredi faizlerindeki \%1 puanlık artışın \% 0.25 , mevduat faizlerindeki \% 1 puanlık artışın \%0.05 puan artmış olduğu belirlenmiştir. Öte yandan enflasyon oranındaki \%1 puanlık artışın, ticari kredi faizlerini $\% 0.23$ puan, vadeli mevduat faiz oranlarını \%0.59 puan artırmış olduğu görülmüştür. Bu sonuçlara göre Türkiye ekonomisinde uzun dönemde Fisher Etkisi geçerlidir. Son olarak vadeli mevduat faiz oranlarındaki \% 1 puanlık artışın ticari kredi faizlerini \%1.04 artırdığı görülmüş olup, bu sonuç oldukça önemlidir. Bu sonuca göre; vadeli mevduat faizlerinin artmasıyla birlikte, bankaların fon maliyetleri de artmakta ve bunu ticari kredilere fazlasıyla yansitmaktadirlar.

Kısa dönem analizleri serilerin birinci farkı alınmış halleri ve hata düzeltme terimleri değerleri kullanılarak, ARDL yöntemiyle gerçekleştirilmiştir. Kısa dönem analizi sonuçlarına göre; modellerin hata düzeltme terimlerinin katsayıları negatif ve istatistiksel olarak anlamlı çıkmıștır. Bu durumda, modellerin hata düzeltme mekanizmaları çalışmaktadır ve yapılan uzun dönem analizleri güvenilirdir. Ticari kredi faizlerinin kısa dönemde de enflasyonu artırdı̆̆ı, ticari kredi faizlerinin, enflasyon ve vadeli mevduat faizleri tarafından artırıldığı belirlenmiştir. Ayrıca enflasyonun, kısa dönemde vadeli mevduat faizleri üzerindeki etkisinin istatistiksel olarak anlamlı olmadığ görülmüştür. $\mathrm{Bu}$ sonuçlara göre Türkiye ekonomisinde kısa dönemde Fisher Etkisi geçerli değildir. $\mathrm{Bu}$ durum, fon sahiplerinin, enflasyondaki değişimler karşısında kendilerini hemen korumaya alamadıklarını göstermesi açısından önemlidir.

Seriler arasındaki nedensellik ilişkileri, Toda-Yamamoto (1995) yöntemiyle incelenmiş ve faiz oranlarından enflasyona doğru bir nedensellik ilişkisi söz konusu değilken, sadece enflasyondan vadeli mevduat faiz oranına doğru tek yönlü bir nedensellik ilișkisinin var olduğu bulunmuştur. Bu sonuç; teorik beklentilerimizle ve Fisher Eşitliği ile uyumludur. Yani Türkiyedeki yaygın söylemin aksine faizler enflasyonu değil, ekonomi teorisinde yer aldığ 1 şekliyle enflasyon, faizi etkilemektedir. Enflasyon arttıkça, vadeli mevduat sahipleri, reel kazançlarını koruyabilmek için bankalardan daha fazla faiz talep etmektedirler.

Bu çalışmadan elde edilen bulgulara dayanarak; Türkiyede enflasyon ile faizler arasında yakın bir etkileşimin olduğu, etkileşimin yönünün faizden enflasyona değil, enflasyondan faize doğru olduğu, bu nedenle ülkede makroekonomik istikrarı sağlamaya yönelik politikalar geliştirilirken, öncelikle enflasyonu düşürücü politikalara ağırlık verilmesinin gerektiği ifade edilebilir. 


\section{KAYNAKÇA}

Adam, A. M. and Ofori, D. (2017). Validity of International Fisher Effect in the West African Monetary Zone. Journal of Economic Cooperation and Development, 38(3), 121-144.

Altunöz, U. (2018). Investigating the Presence of Fisher Effect for the China Economy. Investigating the Presence of Fisher Effect for the China Economy, Sosyoekonomi, 26(35), 27-40.

Akpınar, R., Taşc1, K. ve Özsan, M. E. (2013). Hoşnutsuzluk Endeksine Göre Türkiye’de Bölgesel Farkll1ık. Uluslararası Avrasya Sosyal Bilimler Dergisi, 4(10), 59-70.

Andrea, S. O. and Rodrigo, G. M. (2015). Finding International Fisher Effect to Determine The Exchange Rate Through The Purchasing Power Parity Theory: The Case Of Mexico During The Period 1996-2012. Applied Econometrics and International Development, 15(1), 97-110.

Alper, F. Ö. (2017). Türkiye’deki Enflasyon ve Nominal Faiz Oranı İlişkisinin Analizi: Bayer-Hanck Eşbütünleşme Testi. 3rd International Congress on Political, Economic and Social Studies (ICPESS), 09-11 Nov., Niğde.

Argyro, K. (2010). Testing the Fisher Effect in OECD Countries : An Empirical Investigation. University of Macedonia, Master of Economics Field: Applied Economics and Finance.

ASMMMO (2018). Ekim / 2018 TÜFE ve Yİ-ÜFE Değişim Oranları. (Yayın Tarihi: 5 Kasım 2018).http:// www.asmmmo.org.tr/haber-detay/ekim-2018-tufe-ve-yi-ufe-degisim-oranlari/3167, [Erişim Tarihi: 18.02.2019].

Ayub, G., Rehman, N.U., Iqbal, M., Zaman, Q. and Atif, M. (2014). Relationship between Inflation and Interest Rate: Evidence from Pakistan. Research Journal of Recent Sciences, 3(4), 51-55.

Babalola, O. O., Danladi, J. D., Akomolafe, K. J. and Ajiboye, O.P. (2015). Inflation, Interest Rates and Economic Growth in Nigeria. European Journal of Business and Management, 7(30), 91-102.

Başar, S. ve Karakuş, K. (2017). Fisher Hipotezi: Türkiye İçin Tahmini. Uluslararası Sosyal Araştırmalar Dergisi, 10(54), 794-803.

Bayat, T., Kayhan, S. and Tasar, I (2018). Re-Visiting Fisher Effect for Fragile Five Economies. Journal of Central Banking Theory and Practice, 2, 203-218.

Benazić, M. (2013). Testing the Fisher Effect in Croatia: An Empirical Investigation. Economic Research, 26(1), 83-102.

Beyer, A., Haugh, A. A. and Dewald, W. G. (2009). Structural Breaks, Cointegration and the Fisher Effect. ECB Working Paper, No. 1013.

CNN (2019). Sudan'da 1 yıl süreyle OHAL ilan edildi. (Yayın Tarihi: 22 Şubat 2019). https://www.cnnturk.com/ turkiye/sudanda-1-yil-sureyle-ohal-ilan-edildi,[Erişim Tarihi: 19.02.2019].

Coppock, L. and Poitras, M. (2000). Evaluating the Fisher Effect in Long Term Cross-Country Averages. International Review of Economics and Finance, 9, 181-192.

Dickey, D.A. and Fuller, W. A. (1981). Distribution of the Estimators for Autoregressive Time Series with A Unit Root. Econometrica, 49, 1057-1072.

Doğan, B., Eroğlu, Ö. ve Değer, O. (2016). Enflasyon ve Faiz Oranı Arasındaki Nedensellik İlişkisi: Türkiye 
Örneği. Çankırı Karatekin Üniversitesi İktisadi ve İdari Bilimler Fakültesi Dergisi, 6(1), 405-425.

Engle, R.F. and Granger, C.W.J. (1987). Co-integration and Error Correction: Representation, Estimation and Testing. Econometrica, 55, 251-276.

Eroğlu, N. ve Eroğlu, İ. (2009). Enflasyon Hedeflemesi Rejimi Çerçevesinde Türkiye Cumhuriyet Merkez Bankası'nın Kredibilite ve Hesap Verebilirlik Sorunu. Maliye Finans Yazıları Dergisi, 23(85), 79-109.

EVDS (2019a). Bankalarca Açılan Kredilere . Uygulanan Ağırlıklı Ortalama Faiz Oranları (Akım Veriler,\%) (Haftalık). https://evds2.tcmb.gov.tr/index.php?/evds/serieMarket, [Erişim Tarihi: 23.02.2019].

EVDS (2019b). Bankalarca Açılan Mevduatlara Uygulanan Ağırlıklı Ortalama Faiz Oranları (Akım \%)(Haftalık). https://evds2.tcmb.gov.tr/index.php?/evds/serieMarket, [Erişim Tarihi: 23.02.2019].

EVDS (2019c). Fiyat Endeksi (Tüketici) (2003=100) (TÜİK) (Aylık). https://evds2.tcmb.gov.tr/index.php?/evds/ serieMarket, [Erişim Tarihi: 23.02.2019].

Fama, E. (1975). Short-term interest rates as predictors of inflation, American Economic Review, 65(3), $269-282$.

Fisher, I. (1930). The Theory of Interest. MacMillan, New York.

Granger, C.W.J. and Newbold, (1974). Spurious Regressions in Econometrics. Journal of Econometrics, 2, 111 120.

Gregory, A. W. ve Hansen, B. E. (1996). Residual-Based Tests for Cointegration in Models With Regime Shifts. Journal of Econometrics, 70(1): 99-126.

Hacıoğlu, V. ve Yerlikaya, Ö. (2014). Fisher Hipotezi ve Beklentilerin Rolü. İktisat Fakültesi Mecmuası, 64(2), $109-130$

Jareño, F. and Tolentino, M. (2013). The Fisher Effect: a Comparative Analysis in Europe. Jökull Journal, 63(12), 201-2012.

Johansen, S. (1988). Statistical Anaylsis of Cointegrating Vectors. Journal of Economic Dynamics and Control. 12, 231-254.

Johnston, J. and Dinardo, J. (1997). Econometric Methods. (Fourth Edition), McGraw-Hill Companies, United States.

Khumalo, L. C., Mutambara, E. and Assensoh-Kodua, A. (2017). Relationship between Inflation and Interest Rates in Swaziland Revisited. Banks and Bank Systems, 12(4), 218-226.

Lebe, F. ve Arda Özalp, L. F. (2016). Fisher Hipotezinin Alternatif Faiz Oranları İle Türkiye Ekonomisi Açısından Analizi. Dokuz Eylül Üniversitesi İktisadi ve İdari Bilimler Fakültesi Dergisi, 31(1), 95-122.

Lee, K. F. (2007). An Empirical Study of the Fisher Effect and the Dynamic Relation Between Nominal Interest Rate and Inflation in Singapore. MPRA Paper No. 12383.

Mishkin, F. S. (1991). Is the Fisher Effect for Real? A Reexamination of the Relationship Between Inflation and Interest Rates. NBER Working Paper, No. 3632, 1 - 64.

Pesaran, M. H., Shin, Y. and Smith, R. J. (2001). Bounds testing approaches to the analysis of Level Relationships. Journal of Applied Econometrics, 16(3), 226-339. 
Philips, P.C.B. and Perron, P. (1988). Testing For a Unit Root in Time Series Regression. Biomètrika, 75(2), 336346.

Özatay, F. (2009). Finansal Krizler ve Türkiye. (1. Baskı). Doğan Kitap, İstanbul.

Sabanc1, T. (2018). Meiji Restorasyonunun Askeri Kökenleri ve Japonya Militarizminin 1930'lardaki Darbe Girişimleri Üzerine Kısa Bir Değerlendirme. AVRASYA Uluslararası Araştırmalar Dergisi, 6(13), 290-302.

Sathye,M., Sharma, D. and Liu, S. (2008). The Fisher Effect in an Emerging Economy: The Case of India. International Business Research, 1(2), 99-104.

Songur, M. (2019). Fourier Yaklaşımı ile Fisher Hipotezini Yeniden Gözden Geçirmek: Türkiye Örneği. S.C.Ü. İktisadi ve İdari Bilimler Dergisi, 20(2), 1 - 15.

Sözcü (2018). Venezuela'da enflasyon oranı yüzde 1 milyonu aştı. (Yayın Tarihi: 11 Aralık 2018). https://www. sozcu.com.tr/2018/ekonomi/venezuelada-enflasyon-orani-yuzde-1-milyonu-asti-2789122/, [Erişim Tarihi: 20.02.2019].

Taban, S. ve Şengür, M. (2016). Türkiye’de Enflasyonun Kaynağının Belirlenmesine Yönelik Ekonometrik Bir Analiz. Erciyes Üniversitesi İktisadi ve İdari Bilimler Fakültesi Dergisi, 47, 47-64.

Tarı, R. (2012). Ekonometri. Umuttepe Yayınları, Kocaeli.

Toda, H. Y. and Yamamoto, T. (1995). Statistical Inferences in Vector Autoregressions with Possibly Integrated Processes. Journal of Econometrics, 66, 225-250.

Torun, M. ve Karanfil, M. (2016). 1980-2013 Dönemi Türkiye Ekonomisinde Enflasyon ve Faiz Oranı Arasındaki İlişki. Yönetim Bilimleri Dergisi, 14(27), 473-490.

Tunalı, H. ve Erönal, Y. Y. (2016). Enflasyon ve Faiz Oranı İlişkisi: Türkiye’de Fisher Etkisinin Geçerliliği. Süleyman Demirel Üniversitesi İktisadi ve İdari Bilimler Fakültesi Dergisi, 21(4), 1415-1431.

Uribe,M. (2018). The Neo-Fisher Effect: Econometric Evidence from Empirical and Optimizing Models. http:// www.columbia.edu/ mu2166/neoFisher/fisher.pdf, [Erişim Tarihi: 21.03.2019].

Uslu, H. (2018a). Dış borç ekonomik büyüme ilişkisi: Türkiye Uygulaması. Erciyes Üniversitesi, Sosyal Bilimler Enstitüsü İktisat Anabilim Dalı İktisat Bilim Dalı, Yayımlanmamış Yüksek Lisans Tezi.

Uslu, H. (2018b). Türkiye’de Doğrudan Yabancı Sermaye Yatırımları ve Ekonomik Büyüme İlişkisi: Yapısal Kırılmalı Bir Analiz. Akademik Sosyal Araştırmalar Dergisi, 6(69), 507-529.

Uslu, H. (2018c). Ekonomik Büyüme ve İşsizlik İlişkisinin Türkiye Ekonomisindeki Yeni Gelişmeler Çerçevesinde İncelenmesi. Social Sciences Studies Journal, 4(17), 1515-1531.

Vogelsang, T. J. ve P. Perron. (1998). Additional Test forUnitRootAllowingfor a Break in the Trend Function at an Unknown Time. International EconomicReview. 39, 1073-1100.

Westerlund, J. (2008). Panel Cointegration Tests of The Fisher Effect. Journal of Applied Econometrics, 23, 193233.

World Bank (2019a). Inflation, consumer prices (annual \%). https://data.worldbank.org/ indicator/FP.CPI. TOTL.ZG?view=chart, [Erişim Tarihi: 26.02.2019]. 
World Bank (2019b). Deposit interest rate (\%). https://data.worldbank.org/indicator/FR.INR.DPST?view=chart, [Erişim Tarihi: 26.02.2019].

Yamak, R. ve Abdioğlu, Z. (2007). Fisher Hipotezinin Testi: Güçlü ve Zayıf Form. Kahramanmaraş Sütçü İmam Üniversitesi Sosyal Bilimler Dergisi, 4(1-2), 1 - 9.

Yılancı, V. (2009). Fisher Hipotezinin Türkiye için Sınanması: Doğrusal Olmayan Eşbütünleşme Analizi. Atatürk Üniversitesi İktisadi ve İdari Bilimler Dergisi, 23(4), 205 - 213.

Yıldırım, K., Karaman, D. ve Taşdemir, S. (2009). Makroekonomi. (8. Baskı). Seçkin Yayınevi, Ankara.

Yıldız, Ş. ve Başar, S. (2018). Türkiye’de Enflasyon, Faiz Oranı ve Döviz Kuru Arasındaki İlişkinin Nedensellik Analizi. Electronic Turkish Studies, 13(7), 309-328. 


\section{EKLER}

\section{Ek 1: Veri Setine Ait Tanımlayıcı İstatistikler}

\begin{tabular}{|l|c|c|c|}
\hline Veri Setine Ait Özellikler & ENF & KF & MF \\
\hline Ortalama & 12.05 & 19.69 & 15.60 \\
\hline Ortanca & 8.88 & 16.47 & 13.53 \\
\hline Maksimum & 73.16 & 59.30 & 46.24 \\
\hline Minimum & 3.99 & 8.42 & 7.53 \\
\hline Std. Sapma & 10.43 & 10.70 & 8.34 \\
\hline Çarpıklık & 3.63 & 1.75 & 1.94 \\
\hline Basıklık & 18.02 & 5.71 & 6.34 \\
\hline Jarque-Bera Normality Testi & 2377.33 & 167.65 & 223.20 \\
\hline Jarque-Bera Normality Testi Olasılık Değeri & 0.00 & 0.00 & 0.00 \\
\hline Gözlem Sayısı & 205 & 205 & 205 \\
\hline
\end{tabular}

Not: Tablodaki verilere bakıldığında; standart sapmalarının yüksek olmadığı görülmekte olup, bu durum, yapılacak analizler sonucunda değişen varyans sorunu ile karşılaşılması olasılığını azaltacaktır. Analizde kullanılan gözlem sayısının ise oldukça yüksek olduğu görülmektedir.

\section{Ek 2: Korelasyon Matrisi}

\begin{tabular}{|l|c|c|c|}
\hline Değişkenler & ENF & KF & MF \\
\hline ENF & 1 & 0.87 & 0.86 \\
\hline KF & 0.87 & 1 & 0.96 \\
\hline MF & 0.86 & 0.96 & 1 \\
\hline
\end{tabular}

Not: Korelasyon, serilerin birlikte hareket etme derecelerinin bir göstergesidir. Korelasyon katsayılar (-1) ile $(+1)$ arasında değerler almaktadır. Korelasyon katsayısının (-1) veya (+1)'e yaklaşması, değişkenler arasındaki ilişkinin güçlü olduğunu göstermektedir. Tabloya göre, Ticari kredi faizleri ve mevduat faizleri ile enflasyon arasında oldukça yüksek ilişkiler vardır. Diğer yandan mevduat faizleri ile ticari kredi faizleri arasındaki ilişkilerin çok daha yüksek (0.96) olduğu görülmektedir. 

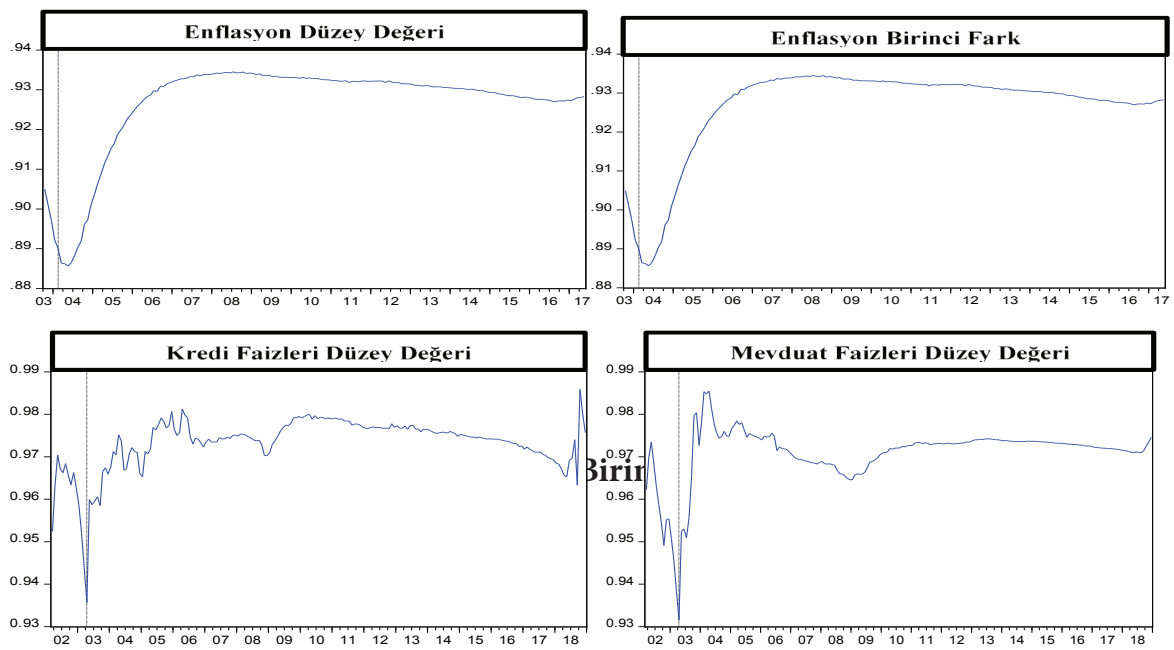

\section{Ek 4: CUSUM ve CUSUMQ Grafikleri}
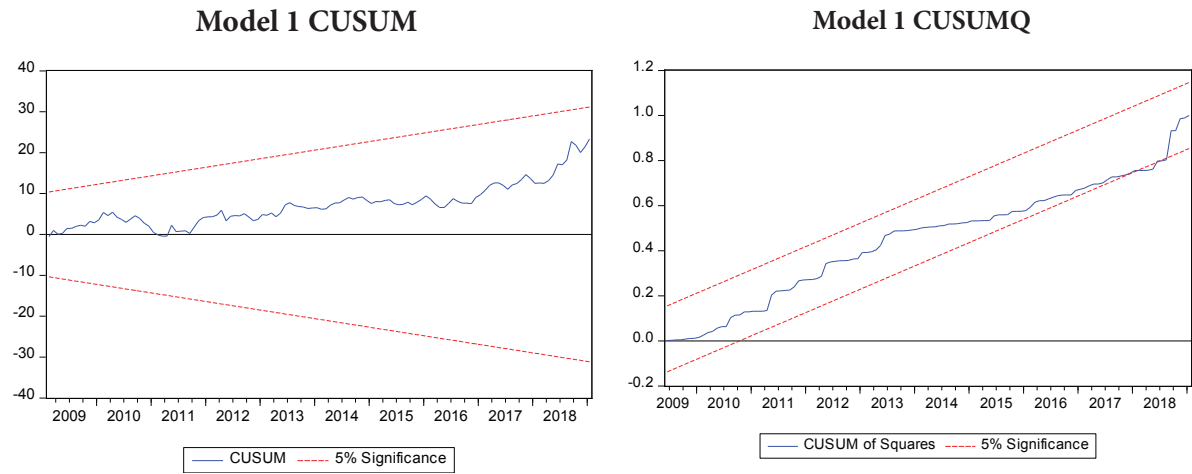

Model 2 CUSUM

Model 2 CUSUMQ
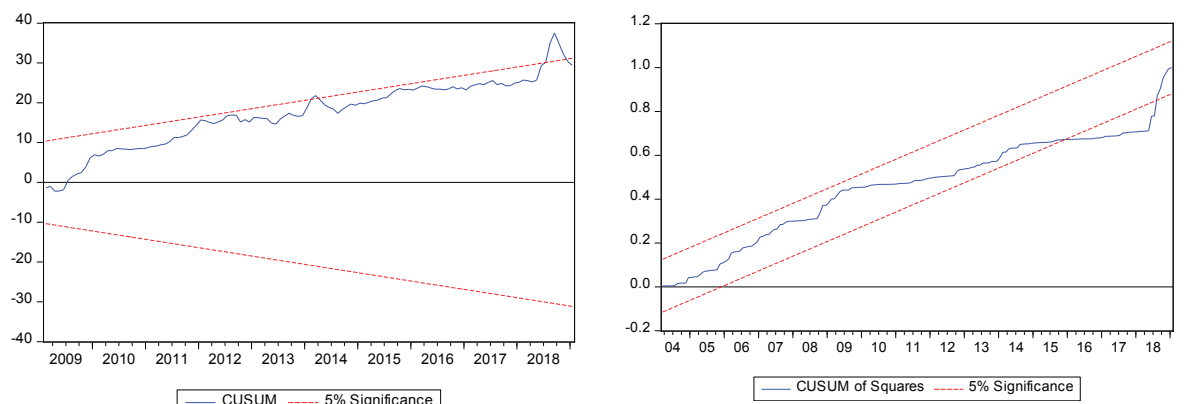

Enflasyon ile Mevduat ve Kredi Faizleri Arasındaki İlişki: Türkiye İçin Fisher Eşitliği Çerçevesinde Ekonometrik Bir Analiz 
Model 3 CUSUM

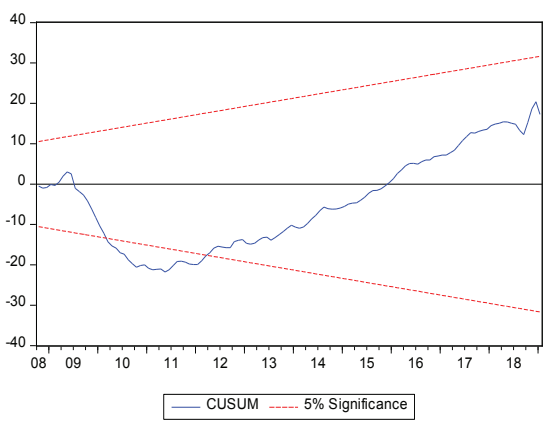

Model 3 CUSUMQ

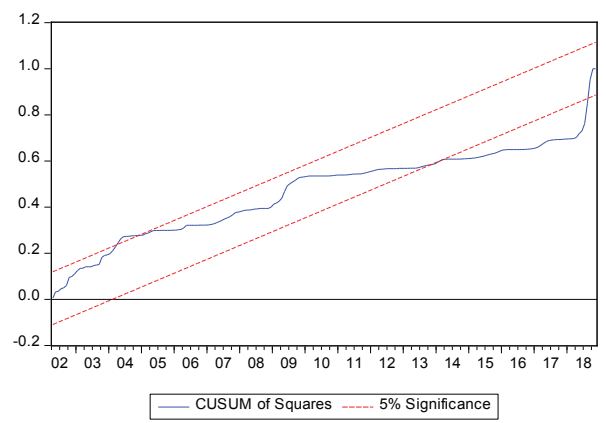

Not: Bu grafiklerin genel olarak güven aralıkları içinde kalması, yapılan analizlerin istikrarlı olduğunu göstermektedir.

\section{Ek 5: İdeal Gecikme Uzunluğu Belirleme İşlemi Sonucu}

VAR Lag Order Selection Criteria

Endogenous variables: ENF KF MF

Exogenous variables: $\mathrm{C}$

Date: 02/26/19 Time: 20:32

Sample: 2002M01 2019M01

\begin{tabular}{ccccccc}
\hline Lag & LogL & LR & FPE & AIC & SC & HQ \\
\hline & & & & & & \\
\hline & -1636.613 & NA & 3402.225 & 16.64582 & 16.69581 & 16.66606 \\
1 & -765.3640 & 1707.117 & 0.537088 & 7.892020 & 8.092013 & 7.972979 \\
2 & -722.8993 & 81.91160 & 0.382409 & 7.552277 & $7.902264^{*}$ & $7.693954^{*}$ \\
3 & -712.4029 & 19.92724 & 0.376708 & 7.537085 & 8.037065 & 7.739481 \\
4 & -702.7241 & 18.08020 & 0.374239 & 7.530194 & 8.180168 & 7.793308 \\
5 & -690.8776 & 21.76868 & 0.363760 & 7.501295 & 8.301264 & 7.825128 \\
6 & -681.2364 & 17.42262 & 0.361664 & 7.494786 & 8.444748 & 7.879338 \\
7 & $\mathbf{- 6 6 7 . 9 1 1 4}$ & $\mathbf{2 3 . 6 7 3 8 6 *}$ & $\mathbf{0 . 3 4 6 4 7 4 *}$ & $\mathbf{7 . 4 5 0 8 7 7 *}$ & $\mathbf{8 . 5 5 0 8 3 4}$ & $\mathbf{7 . 8 9 6 1 4 8}$ \\
8 & -665.7981 & 3.690196 & 0.372056 & 7.520793 & 8.770744 & 8.026783 \\
\hline
\end{tabular}

* indicates lag order selected by the criterion

LR: sequential modified LR test statistic (each test at 5\% level)

FPE: Final prediction error

AIC: Akaike information criterion

SC: Schwarz information criterion

HQ: Hannan-Quinn information criterion

Not: $\mathrm{Bu}$ tablodaki sonuçlara göre; LR, FPE ve AIC kriterlerine göre ideal gecikme 
uzunluğu (7)'dir.

Ek 6: AR Karakteristik Polinomunun Ters Kökler Grafiği

Inverse Roots of AR Characteristic Polynomial

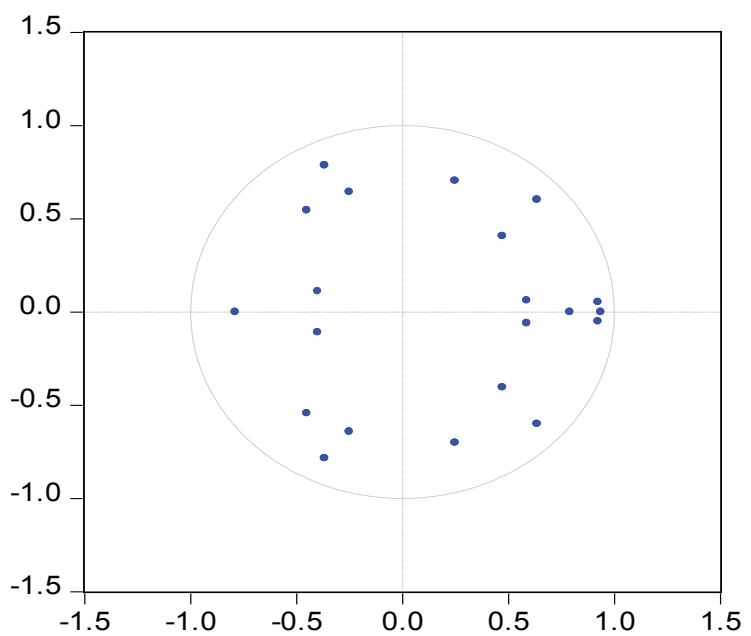

Not: Noktalar birim çember içinde kaldığı için (7) gecikmeli VAR modeli ve bu modele dayanarak gerçekleştirilen Toda-Yamamoto (1995) nedensellik testi sonuçları güvenilirdir. 